\title{
A phylogenetic perspective on diversity of Galatheoidea (Munida, Munidopsis) from cold-water coral and cold seep communities in the western North Atlantic Ocean
}

\author{
D. Katharine Coykendall ${ }^{1 *}$, Martha S. Nizinski ${ }^{2}$, Cheryl L. Morrison ${ }^{1}$ \\ *corresponding author \\ ${ }^{1}$ US Geological Survey, Leetown Science Center - National Fish Health Laboratory, 11649 Leetown Rd., \\ Kearneysville, WV 25430 \\ ${ }^{2}$ NMFS National Systematics Laboratory, Smithsonian Institution, P.O. Box 37012, NHB, MRC-153, \\ Washington, DC 20013-7012
}

Keywords: Munida, Munidopsis, squat lobster, phylogenetics, biodiversity, marine invertebrates, benthos, species diversity, associates, Atlantic Ocean, Gulf of Mexico, COI barcoding

Abbreviations: Northwestern Atlantic Ocean (NWA), Gulf of Mexico (GOM), cytochrome oxidase subunit I gene (COI), mitochondrial DNA (mtDNA), cold-water coral (CWC), biogeographic province (BGP)

\begin{abstract}
Squat lobsters (Galatheoidea and Chirostyloidea), a diverse group of decapod crustaceans, are ubiquitous members of the deep-sea fauna. Within Galatheoidea, the genera Munida and Munidopsis are the most diverse, but accurate estimates of biodiversity are difficult due to morphological complexity and cryptic diversity. Four species of Munida and nine species of Munidopsis from cold-water coral (CWC) and cold seep communities in the northwestern Atlantic Ocean (NWA) and the Gulf of Mexico (GOM) were collected over eleven years and fifteen research cruises in order to assess faunal associations and estimate squat lobster biodiversity. Identification of the majority of specimens was determined morphologically. Mitochondrial COI sequence data, obtained from material collected during these research cruises, was supplemented with published sequences of congeners from other regions. The phylogenetic analysis of Munida supports three of the four NWA and GOM species (M. microphthalma, M. sanctipauli, and M. valida) as closely related taxa. The fourth species, Munida iris, is basal to most other species of Munida, and is closely related to $M$. rutllanti, a species found in the northeastern Atlantic Ocean (NEA). The majority of the nine species of Munidopsis included in our analyses were collected from chemosynthetic
\end{abstract}


cold seep sites from the GOM. While seep taxa were scattered throughout the phylogenetic tree, four of these species (Munidopsis livida, M. similis, M. bermudezi, and M. species A) from the NWA and the GOM were part of a large eighteen-species clade that included species collected from Pacific Ocean chemosynthetic habitats, such as hydrothermal vents and whale falls. Shinkaia crosnieri was the sister taxon to the chemosynthetic clade, and M. livida was the most basal member of this clade. Munidopsis sp. $B$, an undescribed species with representative individuals collected from two GOM chemosynthetic sites, exhibited the largest genetic distance from other northern Atlantic species. Generally, intraspecific diversity was lower and patterns of haplotype diversity more simple in species of Munidopsis relative to Munida. This study puts two genera of NWA and GOM squat lobsters into a population genetic and phylogenetic context with regard to biogeography and habitat to enhance understanding of the history and evolutionary trajectories of these morphologically and ecologically diverse groups.

\section{Introduction}

Squat lobsters are ubiquitous members of the deep-sea macrofauna. They are a polyphyletic, diverse group of anomuran crabs that derive their common name from their lobster-like morphology with an elongated abdomen tucked under the thorax and elongated chelipeds (Baba et al., 2011). Marine squat lobsters (Chirostyloidea: Chirostylidae Ortmann, 1892, Kiwaidae Macpherson, Jones and Segonzac, 2005, Eumunididae Milne Edwards and Bouvier, 1900; Galatheoidea: Galatheidae Samouelle 1819, Munidopsidae Ortmann 1898, Munididae Ahyong, Baba, Macpherson and Poore, 2010) comprise approximately 1,000 species worldwide (Schnabel et al., 2011), with many not yet formally described. Two genera within the Galatheoidea, Munida (Munididae) and Munidopsis (Munidopsidae), are the most diverse, with over 250 and 225 species, respectively (Macpherson and Baba 2011). Most species of Munida and Munidopsis live in deep waters. The majority of species of Munida are found at continental shelf and slope depths, whereas species of Munidopsis are found mainly on continental slopes and abyssal plains (Baba et al., 2008; Macpherson and Baba 2011).

Knowledge of squat lobster biodiversity has improved in recent decades, allowing for a comparison of broad-scale biogeographic patterns in species distributions and centers of endemism (Schnabel et al., 2011). Schnabel et al. (2011) defined ten distinct biogeographic regions, with highest diversity in the tropical western Pacific. The western Atlantic Ocean (WA) biogeographic province (BGP) sensu Schnabel et al. (2011) is an area that extends from the New England coast of the United States, to the southern coast of Brazil, and westward to include all of the GOM. Based on the proportion of endemic species, the WA 
province is one of three global centers of endemism. In the WA, approximately 35 species of Munida are recognized (Baba et al., 2008) of which 20 have been reported from the GOM (Felder et al., 2009) and 48 species of Munidopsis occur in the WA (Baba et al., 2008) of which 36 have been reported from the GOM (Felder et al., 2009).

Within the WA province north of the equator, encompassing the GOM and the eastern continental shelf and slope of the United States (NWA), two habitat types greatly influence patterns and levels of biodiversity: chemosynthetic cold seep and cold-water coral (CWC) communities. Anomurans in general and galatheoids in particular, are the dominant top predator/scavengers found in reducing habitats (Chevaldonné and Olu 1996). Members of the genus Munidopsis are frequently found associated with extreme environments, including hydrothermal vents and cold seeps (Martin and Haney 2005). In fact, Munidopsis is the most speciose and widespread of all hydrothermal vent-associated taxa (Martin and Haney 2005). Species of Munidopsis have been reported from these habitats since their discovery in the late 1970s (Chevaldonné and Olu 1996). Galatheoids were also recorded from cold seep environments when these reducing habitats were first discovered in the GOM during the mid-1980s (Paull et al., 1984). Moreover, quantitative surveys of mega- and macro-invertebrates conducted in chemosynthetic cold seep habitats of the GOM (e.g., MacDonald et al., 1989; Carney 1994; Bergquist et al., 2003; Cordes et al., 2006; 2007; 2009) reported squat lobsters as being important, and sometimes dominant, members of seepassociated fauna. Cold seeps were not known to occur on the continental slope off the Atlantic coast of North America until the discovery of a methane seep at Blake Ridge Diapir off the coast of South Carolina (Van Dover et al., 2003). Given that multibeam water-column backscatter data suggests more than 570 gas plumes exist from Cape Hatteras to Georges Bank (Skarke et al., 2014), additional cold seep faunal communities are likely to be discovered (e.g. Brothers et al., 2013; Demopoulos et al., 2014; Quattrini et al., 2015), thus increasing the possibility for discovery and collection of additional of squat lobster species.

CWC habitats can be hot spots of biodiversity, with as many as 1,300 species found associated with Lophelia pertusa reefs in the North Atlantic (Rogers 2004). Coral species richness influences variation in fish and crustacean assemblages in several submarine canyons off the coast of New England (Quattrini et al., 2015). Large reef structures of colonial stony coral support diverse invertebrate assemblages in the northern GOM (Cordes et al., 2008) and ophiuroid assemblages in the southwestern Pacific Ocean (O'Hara et al., 2008). Bioherms formed by Lophelia pertusa and Oculina varicosa punctuate the continental margin of the southeastern United States (Reed and Ross 2005; Reed et al., 2006), with both Munida and Munidopsis noted as dominant invertebrate coral associates (Ross and Nizinski, 2007). 
Comprehensive taxonomic information is lacking for many galatheoids. Squat lobsters are often sampled opportunistically or photographed in lieu of collections. Many species and even genera of galatheoids are morphologically similar and slight morphological differences have proven useful for taxonomic identification for certain species (e.g., Cabezas et al., 2011a). Given the potential importance of slight morphological differences, identifications from photographs are extremely problematic (Chevaldonné and Olu, 1996; pers. obs.). The lack of specific identifications has led to vague, general references of these decapods at vents and seeps (Chevaldonné and Olu 1996; Martin and Haney 2005; Cordes et al., 2005; 2010), CWC sites (Cordes et al., 2008), and other deep-sea habitats where photographs, not specimens, were used to identify species. In situ photographs taken during recent expeditions to seep sites in the GOM show live coloration; however, limited information exists from early literature to compare with observations. Furthermore, the majority of galatheoid species were described in the 18th and early 19th century. Those species described from historical, museum collections often lack corresponding ecological metadata. Conversely, taxa mentioned in association with contemporary ecological studies often are not identified to the species or even genus level making these two sources of information difficult to combine and compare (Chevaldonné and Olu 1996). As a result, it is difficult to assess and compare information from these two different but equally important accounts of associated fauna. Thus, like many deep-sea taxa, the total diversity of galatheoids in deep-sea environments remains unresolved.

Molecular approaches, when used together with morphological data, have proven increasingly useful in species identifications. Genetic approaches provide an independent assessment of species diversity from morphology and may reveal underlying diversity not evident in taxa featuring morphological conservatism. COI (aka DNA) barcoding is a common methodology that may uncover cryptic genetic diversity within a taxon and assign individuals to a species (Hebert et al., 2003; Stoeckle 2003).

Additionally, COI data are used to address questions regarding regional and local diversity and patterns of speciation. Within Crustacea (Costa et al., 2007) and Decapoda (da Silva et al., 2011), COI barcoding assigned individuals to species with some success. For example, combined morphological and molecular approaches confirmed the existence of sibling species of Munida from New Caledonia (Macpherson and Machordom 2005) and Munidopsis in the East Pacific (Jones and Macpherson 2007). Molecular data supported designation of new species when only subtle morphological differences were observed (Macpherson and Machordom 2005; Cabezas et al., 2009; 2011b). In contrast, molecular data corroborated the synonymy of Munida gregaria and M. subrugosa from southern South America, despite apparent morphological differences (Pérez-Barros et al., 2008).

COI barcoding, in combination with other genetic and morphological data, has been used to construct hypotheses of evolutionary relationships among galatheoid species. However, most studies have not 
included species from the WA. For example, Cabezas et al., (2011a) constructed a phylogeny containing 39 species of Munida. Of the species included in the analysis, only M. rugosa from the NEA represented the fauna of the Atlantic Ocean basin. The clade containing M. rugosa was basal to the remaining phylogeny and contained long branches. However, this may be a consequence of insufficient sampling of taxa. The authors specifically recommended the inclusion of species from the Atlantic in future studies to elucidate relationships within Munida further. To date, of the 35 WA species of Munida, none are represented in Genbank. In contrast, Ahyong et al. (2011) included three species of Munidopsis collected from the northern GOM in their phylogeny of Munidopsidae. Their study found the family to be polyphyletic, with the WA species scattered throughout the tree, each sharing clades with species from other oceanic regions. Currently, only four of the 48 species of Munidopsis known from the NWA have DNA barcodes registered in Genbank.

Increased sampling, better-defined taxonomy (incorporating both morphological and molecular data), and discovery of cryptic species has improved species diversity estimates of the Pacific galatheoid fauna. With the application of similar approaches, we expect estimates of galatheoid diversity in the NWA to increase also. In this study, we aim to (1) provide an initial assessment of the species composition of squat lobsters present at chemosynthetic cold seep and CWC habitats on the continental shelf and slope of the WNA, including the GOM; (2) examine species diversity in an evolutionary and phylogenetic context through comparisons with other species in the genera Munidopsis and Munida; (3) expand current phylogenetic knowledge by the addition of information from WNA species; and (4) compare genetic relationships between species with regard to biogeography and habitat (seep vs. coral) to enhance understanding of the history and evolutionary trajectories of these morphologically and ecologically diverse groups.

\section{Materials and Methods}

\subsection{Sampling information}

Squat lobsters were collected on research cruises from 2003-2014 using a variety of sampling methods and research vessels (Table 1). Fourteen GOM sites were sampled from the westernmost, deepest (2746 m) site of Alaminos Canyon 818 (AC818) to the easternmost West Florida Slope (WFS) to the northernmost, shallowest (350 m) Viosca Knoll 826 (VK826) (Figure 1), spanning approximately 1000 $\mathrm{km}$ from west to east and $730 \mathrm{~km}$ from north to south. The remaining GOM sites are clustered in the northern central region and range from 401 to $2192 \mathrm{~m}$ depth. Eight NWA sites were surveyed from 
southernmost Jacksonville bioherms (JAX) to northernmost Corsair Canyon, spanning more than 1700 $\mathrm{km}$ linear distance and 160 to $1701 \mathrm{~m}$ depth. Depth zones were defined as: continental shelf, 0-199 m; upper slope, 200-899 m, lower slope, 900-1999 m, and continental rise, 2000-3999 m (Macpherson et al., 2010; Schnabel et al., 2011). Tissue samples (legs, abdomen tissue, eggs, or entire individuals) were preserved in 70-100\% ethanol. A subset of squat lobsters collected were examined and identified to species level based on morphological characters.

\subsection{Molecular methods}

DNA was extracted from eggs or tissue following either Puregene Tissue or DNeasy protocols (Qiagen). The majority of mitochondrial COI gene fragments were amplified using the universal forward primer, LCO1490 (Folmer et al., 1994) and the reverse primer, COI-H (Machordom and Macpherson 2004). Occasionally, gala_COIF (Jones and Macpherson 2007) or Crust_F2 (Costa et al., 2007) were used in lieu of LCO1490. PCRs were performed with the following concentrations of reagents: 1X GoTaq Flexi PCR buffer (Promega), $2 \mathrm{mM}$ of $\mathrm{MgCl}_{2}$ (Promega), $10 \mathrm{mM}$ of GeneAmp dNTPs (Thermofisher Scientific), 5 $\mu \mathrm{M}$ of each primer, $0-0.4 \mathrm{mg} / \mathrm{ml}$ Bovine Serum Albumin (New England Biolabs), 0.1 unit of GoTaq Flexi (Promega), 2-20 ng of DNA, and laboratory grade water to adjust volume to $25 \mu \mathrm{l}$. PCRs reactions were performed on BioRad or Eppendorff thermalcyclers under the following conditions: initial denaturation of $94^{\circ} \mathrm{C}$ for $3 \mathrm{~min}$, then $29-34$ cycles of $94^{\circ} \mathrm{C}$ for $1 \mathrm{~min}, 50-56^{\circ} \mathrm{C}$ for $1 \mathrm{~min}, 72^{\circ} \mathrm{C}$ for $1 \mathrm{~min}$, and a final extension step of $72^{\circ}$ for $7 \mathrm{~min}$. PCR products were electrophoresed on a $1.5 \%$ agarose gel at $95 \mathrm{~V}$ for 30 min to ensure single band amplification. When more than one band was present, the largest band was cut from the gel and purified using Qiaquick PCR purification spin columns (Qiagen) according to manufacturer's protocol. The purified products were re-suspended in 30-40 $\mu$ l of laboratory grade water. Cycle sequencing for subsequent Sanger sequencing reactions were performed using $1 \mu 1$ of purified PCR as template, $1 \mu \mathrm{l}$ BigDye ${ }^{\circledR}$ Terminator v3.1 Ready Reaction Mix (Thermofisher Scientific), $1 \mu 1$ of $5 \mu \mathrm{M}$ primer, $2 \mu 1$ of 5X Sequencing buffer (Thermofisher Scientific), and $5 \mu 1$ of molecular grade water for a final volume of $10 \mu \mathrm{l}$. Products were sequenced in both forward and reverse directions to assure accuracy of base calls. Cycle sequencing was performed on a BioRad or Eppendorff thermal cyclers under the following conditions: $95^{\circ} \mathrm{C}$ for $3 \mathrm{~min}$, then 29 cycles of $95^{\circ} \mathrm{C}$ for $20 \mathrm{sec}, 50^{\circ} \mathrm{C}$ for $20 \mathrm{sec}$ and $60^{\circ} \mathrm{C}$ for 4 min with final extension of $60^{\circ} \mathrm{C}$ for $5 \mathrm{~min}$. Cycle sequencing products were purified using AGENCOURT ${ }^{\circledR}$ CLEANSEQ ${ }^{\circledR}$ beads (Beckman Coulter) according to the manufacturer's protocol. Final products were re-suspended in 25-30 $\mu 1$ of molecular grade water. Twenty-five microliters of purified product were loaded onto an ABI 3130xl DNA sequencer. 


\subsection{Data analysis}

DNA sequences were edited using Sequencher 5.2.2 (Genecodes). After aligning sequences from both the forward and reverse directions, regions with ambiguous bases were omitted from subsequent analyses. The National Center for Biotechnology Information (NCBI) Genbank nucleotide database was queried with COI consensus sequences from each individual. DNA sequences were aligned and translated into amino acids using the invertebrate mtDNA translation table in MEGA6.06 (Tamura et al., 2013) to ensure no stop codons were present. Uncorrected $p$-distances were estimated (MEGA) to quantify intra- and inter-specific genetic distances of species with sufficient sample sizes (using all available data from individuals from all oceanographic regions; Table S1). Gaps and missing data were treated as partial deletions with a site coverage cutoff of $65 \%$; 500 bootstraps (bs) were employed for statistical significance. DNA sequence summary statistics within species were calculated in DnaSP 5.10.01 (Librado and Rozas 2009). The Drosophila mitochondrial translation table was applied to all datasets. Intraspecific genetic diversity was estimated within species collected for this study with sample sizes of four or greater, and select species reported in Genbank (www.ncbi.nlm.nih.gov/genbank). Haplotype networks were drawn (Network 4.6.1.3; Fluxus Technology Ltd) using a median-joining method coupled with a maximum-parsimony heuristic algorithm (Bandelt et al., 1999) with post-processing to delete superfluous median vectors and links not contained in the shortest networks (Polzin and Daneshmand 2003).

Two phylogenetic methodologies were used to produce trees for each genus. The best-fit evolutionary model was estimated in MEGA including individuals from all species of Munida and Munidopsis registered in Genbank (Table S1). Cervimunida johni was chosen as the outgroup for the phylogeny of Munida (Machordom and Macpherson 2004). Shinkaia crosnieri and Galacantha subspinosa were included in the phylogenetic analysis of Munidopsis, based on the findings of Ahyong et al. (2011) and Leiogalathea laevirostris was chosen as the outgroup. A maximum likelihood (ML) phylogenetic tree was constructed for each genus assuming the best-fit evolutionary model, based on the lowest Bayesian Information Criterion (BIC) score and 500 bs were used to determine significance. Phylogenetic trees were estimated via Bayesian analysis using MrBayes v. 3.1.2 (Huelsenbeck and Ronquist 2001). Sequence alignment files in Fasta format were converted to Nexus format for input into MrBayes using the online tool Alignment Transformation Environment, ALTER (sing.ei.uvigo.es/ALTER/). The resultant parameter estimates from the MEGA best-fit evolutionary model were used as hyper-parameter estimates to provide more informative prior probabilities for the models used in MrBayes for each phylogeny. 
MEGA reports asymmetrical rates of nucleotide change (i.e. separate estimates for $A=>T$ and $T=>A$ where applicable) but MrBayes assumes symmetrical rates. When asymmetrical rates were reported from MEGA, the average between the two was used. All non-default input values used are listed in Table S2. Three independent simulations (nruns=3) were performed per phylogeny starting at different random topologies to ensure the sample space was covered. Five Metropolis-coupled Markov-chain Monte Carlo (MCMC) chains were used (nchains =5) for the analysis of Munida and six chains for Munidopsis due to lack of convergence in preliminary runs. Independent runs are thought to have converged on similar posterior probabilities (PP) of estimated parameters if the effective sample size (ESS) of each parameter is at least 200, the Potential Scale Reduction Factor (PSRF) (Gelman and Rubin 1992) of each parameter is close to 1.00, and the final average standard deviation of split frequencies is near 0.01 (Ronquist et al., 2011). Convergence diagnostics were visualized in Tracer v1.6 (Rambaut et al., 2014). Topological convergence diagnostics were visualized in AWTY (Wilgenbusch et al., 2004; Nylander et al., 2008). Trees were edited in FigTree v1.4.2 (Rambaut, 2014).

\section{Results}

\subsection{Munida}

Seventy-seven individuals identified as species of Munida were collected within their known depth ranges in the WA on the continental shelf and slope of the northeastern United States (NWA) $(\mathrm{N}=41)$, and the GOM (N=36) (Table 1). Four species of Munida were identified from the collections based on morphology: M. iris, M. microphthalma, M. sanctipauli, and M. valida. Other individuals that grouped with these morphologically-verified species in the phylogenetic analyses (see below) but were not examined were indicated with "cf" before the species name and considered conspecifics. Individuals of M. microphthalma were only collected at chemosynthetic cold seep sites in the GOM; none were collected from NWA CWC or seep sites. Munida microphthalma was also the deepest species of Munida sampled. Occurring at depths of 900-1564 m, this was the only species collected on the lower slope. No other species of Munida were collected at chemosynthetic sites. The other three species of Munida $(\mathrm{N}=32)$ occurred at both NWA and GOM sites and were collected from upper slope depths. Munida iris, the most abundant squat lobster species in the samples, was collected at the shallowest continental shelf and upper slope depths (160-520 m). Most individuals of $M$. sanctipauli were collected in the GOM at the two Viosca Knoll sites; a single individual was collected off Cape Fear, North Carolina. No 
individuals of any Munida species were recovered at continental rise depths (2000-3999 m), though sampling effort at these depths was minimal.

\subsubsection{Munida phylogenetics}

All COI sequences generated from this study were entered into Genbank as a population set (popset) with the following accession numbers: KX016541-76; KX022403-79 (Table S1). The phylogenetic dataset compiled for the analysis of relationships within the genus Munida contained 175 individuals, including the outgroup Cervimunida johni, corresponding to 60 taxa (Table S1; Figure 2). Sequences were truncated to 499 nucleotides in the aligned dataset. Genbank sequence JQ348884, identified as Munida intermedia (da Silva et al., 2011), did not group with the two other M. intermedia individuals included in the phylogenetic analyses and is referred to as $M$. intermedia $J Q$ in this study. The best-fit evolutionary model was the general time-reversible model (Tavaré 1986) with a gamma distribution of rate variation and allowing for a proportion of invariant sites $(\mathrm{GTR}+\Gamma+\mathrm{I})$ and a BIC score of 23031.102. The next lowest BIC score was 23158.191. Input parameters and convergence diagnostics for the Bayesian phylogenetic analysis are listed in Table S2. Comparisons of traces between the three runs did not reveal a trend, indicating convergence of the runs (FigureS1: A-C). Marginal distributions of PP of the total length of all branches (TL), the log likelihoods ( $\mathrm{LnL}$ ), and alpha values were concordant between the three runs (Figure S1: D-F). Plots of pairwise comparisons of split frequencies between separate runs illustrate convergence as well (Figure S1: G-I).

In general, support for branching nodes calculated with the Bayesian analysis (PPs) was higher than the bootstrap support values calculated from the ML analysis (Figure 2). Both analyses agreed on the associations between closely-related taxa. Munida valida and M. sanctipauli were more closely related to each other than to M. microphthalma. Munida intermedia JQ, an individual collected from the Bay of Biscay in the NEA (da Silva et al., 2011), was ancestral to M. valida and M. sanctipauli. Both analyses place $M$. microphthalma as the ancestor to $M$. intermedia JQ/M. sanctipauli/M. valida, though with very low support in the ML tree. This four-taxa clade is comprised of species known from the WA BGP. Sister to this clade, though with low statistical support, is M. tiresias, a species from New Caledonia (western Pacific Ocean, WP) and M. lanciara from Taiwan (WP). The fourth species of Munida collected from the WA, $M$. iris, formed a well-supported clade with M. rutllanti (NEA). Both analyses grouped all seven $M$. rutllanti individuals together (ML bs $=0.99$; Bayesian PP $=0.81$ ). The ML tree grouped together all the M. iris individuals, but with low support (0.47). The Bayesian analysis did not place these two species in 
a monophyletic group. The clade containing $M$. iris and $M$. rutllanti was ancestral to most other species of Munida, except for M. gregaria, a species from southern South America (Southeast Pacific, SEP) and New Zealand (Southwest Pacific, SWP), and M. quadrispina, a species from the Northeast Pacific Ocean (NEP). Two other northern Atlantic Ocean species were represented in the analyses: M. intermedia from the NEA and the northeastern coast of Canada (a region not included in Schnabel et al. (2011) as part of a BGP), and M. rugosa, from the NEA. These two species are sister taxa to each other (ML bs $=0.97$; Bayesian PP $=1.00$ ) and form a clade with $M$. delicata, a species from the WP. See Table S1 for references regarding species' sampling locations mentioned above.

\subsubsection{Munida inter-and intra-specific diversity}

Inter-specific genetic distances were computed between northern Atlantic Ocean species of Munida, M. gracilis, $M$. gregaria, and $M$. thoe (Table 2; Table S1). The average uncorrected $p$-distances between species collected from the NWA and GOM was $13.6 \%$ and ranged from $7.1 \%$ (M. valida vs. $M$. sanctipauli) to $16.9 \%$ (M. valida vs. M. iris). In comparison, the average genetic divergence between species from the NEA was $16.2 \%$ and ranged from $10.2 \%$ to $18.2 \%$. The average of genetic divergence comparisons between NWA and NEA species was $14.6 \%$ and ranged from $2.8 \%$ to $19.2 \%$. Including the remaining species (M. gracilis (SWP) M. gregaria (SEP, SWP), and M. thoe (WP)) in all inter-BGP comparisons raised the average to $15.5 \%$ but did not change the range, because comparisons between NWA and NEA species represented both the lowest (M. iris and M. rutllanti) and highest (M. valida and $M$. intermedia) values. Overall, the highest average genetic divergence was documented between species within the NEA, whereas the lowest average was documented between species of the NWA. In general, genetic divergences were higher among species within the NEA than divergences between species from different BGPs. Most divergences larger than those observed in NEA comparisons were between NEA and NWA species.

Intraspecific genetic distances of NWA and GOM Munida ranged from $0.3 \%$ (M. valida, $\mathrm{N}=11$ ) to $1.3 \%$ (M. iris, $\mathrm{N}=40$ ) (Table 3). When additional species of Munida are considered, M. iris still exhibited the highest intraspecific difference but $M$. gregaria had the lowest $(0.2 \%, \mathrm{~N}=110)$. Munida iris also had the largest number of pairwise differences between sequences $(k=6.40)$ and the smallest number of singleton mutations relative to the total number of polymorphic sites, meaning mutations rarely occur only in a single individual. Both $M$. iris and $M$. sanctipauli have haplotype diversities $\left(H_{d}\right)$ greater than $95 \%$. The 
SEP species, $M$. gregaria, had the largest sample size, yet the lowest $H_{d}(0.628), \pi(0.002)$, and $k(0.99)$. Munida valida and $M$. rutllanti share similar values of polymorphic sites $(p)$, number of mutations $(\mu)$, singletons $(s)$, parsimony informative sites (PI), and synonymous (syn) changes. However, $M$. rutllanti has an $H_{d}$ of 0.857 whereas $M$. valida has an $H_{d}$ of 0.727 . The seven $M$. rutllanti sequences also contain three mutations that resulted in an amino acid change (nsyn; Drosophila mitochondrial translation table). Haplotype networks of both M. iris and M. microphthalma, the two species of Munida with the highest sample sizes collected for this study (Figure 3), illustrate the complex evolutionary pathways between COI haplotypes. In both cases, more than one path is possible between the haplotypes and several mutational steps separate different parts of the network. However, the two most common haplotypes within $M$. iris (both N=6), each account for $15 \%$ of the total number of haplotypes in the network, whereas the most common haplotype of $M$. microphthalma accounts for $44 \%$ of all haplotypes.

Haplotypes that occur exclusively in the NWA or GOM are an indication of a biogeographic barrier leading to genetic differentiation of lineages in each oceanic region. Some of the species of Munida exhibited this pattern, although sample sizes were low. Munida microphthalma was only collected at sites in the GOM, however, this species is known to occur throughout the WA and NEA (Baba et al., 2008). Of the four unique NWA haplotypes found in $M$. iris, each was recovered from a single individual and none were shared with GOM. In the $M$. valida dataset, 11 individuals share six haplotypes and of the seven collected from the GOM, six share the most common haplotype with a single individual from the NWA. The ten $M$. sanctipauli in the collection had nine unique haplotypes, however, the single NWA individual shared a haplotype with an individual collected from the GOM.

\subsection{Munidopsis}

Thirty-six individuals collected from the NWA $(\mathrm{N}=9)$ and from the GOM $(\mathrm{N}=27)$ were identified as species of Munidopsis (Table 1). Collections consisted of five described species: M. bermudezi, $M$. curvirostra, . livida, $M$. penescabra, and $M$. similis, and four additional, putative species referred to as Munidopsis sp. A, B, C, and D. Munidopsis sp. C was the most abundant taxon with 17 individuals, 15 of which were collected from various GOM sites. Similarly, M. curvirostra was collected at both NWA (Norfolk Canyon) and GOM (Walker Ridge 269) sites. In contrast, Munidopsis sp. D was only collected from the NWA submarine canyon sites. The remaining taxa were collected only at GOM sites. Threespecies, Munidopsis. sp. A, M. bermudezi, and M. livida, were collected at Alaminos Canyon 818, the western-most and deepest site surveyed (2746 m). Two species, Munidopsis sp. C and M. penescabra, 
collected in the GOM at VK826, occurred at the shallowest depths (350-477 m) sampled. Munidopsis sp. A, Munidopsis sp. B, M. bermudezi, M. livida, and M. similis, were only collected at cold seep sites in the GOM. However, single individuals of Munidopsis sp. C and M. curvirostra were collected at cold seep sites while the remainder were collected at CWC sites. Twenty individuals representing three species occurred at upper slope depths (200-899 m), whereas four species were collected at lower slope depths $(\mathrm{N}=9 ; 1049-1682 \mathrm{~m})$. No species of Munidopsis were captured on the continental shelf (0-199 m), though few species in this genus are known to occur at these shallower depths (Schnabel et al., 2011). Interestingly, no squat lobsters were observed at the two NWA cold seep sites adjacent to Norfolk and Baltimore canyons.

\subsubsection{Munidopsis phylogenetics}

Consensus COI sequences of undescribed species Munidopsis sp. A-D were compared to those in Genbank. Munidopsis sp. A shared 99\% sequence identity (query coverage $=95 \%$; E value $=0.0$ ) with both M. antonii (DQ677685-9) and M. bracteosa (DQ677684). Munidopsis sp. B shared 97\% sequence identity (query coverage $=86 \%$; E value $=0.0$ ) with $M$. longimanus $(\mathrm{JN166770)}$. Munidopsis sp. $\mathrm{C}$ shared $88 \%$ sequence identity (query coverage $=86 \% ; \mathrm{E}$ value $=2 \mathrm{e}^{-179}$ ) and Munidopsis sp. D shared $89 \%$ sequence identity (query coverage $=85 \%$; E value $=0.0$ ) with $M$. comarge $(\mathrm{JN} 166772)$.

The phylogenetic dataset used to interpret relationships between species of Munidopsis contained 84 individuals, including the outgroups, corresponding to 41 taxa (Table S1; Figure 4). Sequences were truncated to 583 nucleotides in the aligned dataset. The best-fit evolutionary model was determined to be T92 (Tamura 1992) $+\Gamma+\mathrm{I}$, which allows for transition/transversion bias and $\mathrm{G}+\mathrm{C}$ content bias, with a BIC score of 13474.85. The next lowest BIC score was 13481.46. Input parameters and convergence diagnostics for the Bayesian phylogenetic analysis are listed in Table S2. Comparisons of traces between the three runs did not reveal a trend, indicating convergence of the runs (FigureS2: A-I; see above (3.1.1) for details).

As was illustrated in the phylogeny of Munida, the phylogenetic analysis of Munidopsis reflects higher statistical support for more recent relationships than internal, more ancestral associations. Species of Munidopsis collected from the NWA (this study) were scattered throughout the phylogenetic tree (Figure 4 ), showing no pattern of grouping by ocean basin. Two major clades were present, each with moderate PP support (Figure 4; A and B). Within Clade A, the Elasmonotus Group (Ahyong et al., 2011) was 
ancestral to the rest of the clade (Figure 4; A). Two of the undescribed species of Munidopsis fell within Clade A: Munidopsis sp. C and Munidopsis sp. D. These taxa grouped with M. comarge from the SWP, M. trifida, from the WP, SWP and Indian Ocean (IO), and M. erinacea from the GOM. Additionally, $M$. penescabra (GOM) grouped with its sister taxon, M. opalescens (SEP) and M. polymorpha from the NEA. Munidopsis curvirostra formed a small clade with $M$. crenatirostris and M. cylindrophthalma from the WP. Finally, Munidopsis sp. B was sister to another GOM species, M. longimanus. These two species grouped with M. quadrata reported from the Pacific coast of Canada (NEP) and Chile (SEP), and Munidopsis sp. 1 from SEP. See Table S1 for references regarding species' sampling locations mentioned above.

Shinkaia crosnieri, a species found at hydrothermal vents and cold seeps (Yang et al., 2016), was ancestral to the second clade, Clade B (Figure 4; B). Of the 18 taxa included in Clade B, 13 occur at hydrothermal vents, cold seeps, or whale falls. Individuals of M. kensmithi, M. tiburon, $M$. segonzaci, and $M$. antonii represented in the tree were collected from non-chemosynthetic sites in the NEP(Jones and Macpherson 2007). Interspecific relationships in Clade B had low statistical support after the Munidopsis sp. A split, except for sister relationships between $M$. bermudezi and $M$. cascadia, a species known from the NEP ( $\mathrm{PP}=1.00)$, and between the WA species pair M. aries and M. albatrossae ( $\mathrm{PP}=1.00)$. Munidopsis livida and M. similis were basal members of Clade B. Munidopsis sp. A, collected at cold seep sites in the GOM, grouped with several other species of Munidopsis known to occur at chemosynthetic sites. These include M. scotti, M. bracteosa, M. recta, M. vrijenhoeki, M. albatrossae, M. cascadia, M. lauensis, and Munidopsis sp. 2 in the Pacific, as well as M. exuta from the Atlantic.

\subsubsection{Munidopsis inter-and intraspecific diversity}

Inter-specific genetic distances were computed between all northern Atlantic Ocean taxa, as well as $M$. recta and M. lauensis, using data from this study, supplemented with data from Genbank (Table 4; Table S1). Though Munidopsis antonii is reportedly a cosmopolitan species, all individuals registered in Genbank were collected off California and therefore excluded from the intraspecific genetic distance analysis between strictly Atlantic Ocean taxa. Uncorrected $p$-distances between species collected in this study ranged from $9.7 \%$ (Munidopsis sp. A vs. M. similis) to 23.8\% (Munidopsis sp. B vs. Munidopsis sp. D). Average genetic divergence between species within the WA (NWA + GOM) was $18.7 \%$ and ranged from 2.7\% (Munidopsis sp. B vs. M. longimanus) to 23.8\% Munidopsis sp. B vs. Munidopsis sp. D). Pair- 
wise genetic divergences within the WA were similar to comparisons between species from different BGPs, which averaged $17.8 \%$ and ranged from $2.0 \%$ (M. exuta vs. M. recta) to $24.8 \%$ (Munidopsis sp. B vs. M. lauensis). The largest pairwise distances were generally between Munidopsis sp. B and other species collected for this study.

Intra-specific genetic diversity was low for all species of Munidopsis with adequate sample size. Both Munidopsis sp. A and B were excluded from intraspecific analyses due to small samples sizes. However, the two individuals of Munidopsis sp. A had unique haplotypes that differed by two nucleotides and the two individuals of Munidopsis sp. B had unique haplotypes that differed by a single nucleotide. No intraspecific genetic diversity ( $p$-distance $=0.00$ ) was observed in Munidopsis sp. D, the taxon with the lowest sample size $(\mathrm{N}=4)$, or within M. lauensis, the taxon with the largest sample size $(\mathrm{N}=116)$ (Table 5). Munidopsis sp. C (N=17) had the largest intraspecific diversity (0.004) and the most haplotypes $(H=9)$ of all munidopsid species included in the analysis. In both M. curvirostra and M. lauensis, all mutations were singletons (Parsimony Informative Site $(P I)=0) . H_{d}$ ranged widely from 0.00 to 0.86 , and were lower than most of the $H_{d}$ values observed for species of Munida. Most other indices of genetic diversity for these species of Munidopsis were low. Two species, Munidopsis sp. C and M. lauensis, had much higher $\mathrm{G}+\mathrm{C}$ content than the other species of Munidopsis as well as all species of Munida analyzed.

Insufficient sample sizes for Munidopsis spp. prevented testing for a definitive biogeographic break in genetic differentiation between the GOM and NWA. However, notably, the only individual of $M$. curvirostra collected from a GOM cold seep site differed by four mutations relative to its conspecifics in the WNA, all of which shared a single haplotype. Also, genetic diversity was higher in the GOM for Munidopsis sp. C, where eight haplotypes were recovered (Figure 5). The GOM haplotypes were at least two mutational steps removed from the single NWA haplotype that was shared by two individuals collected off the coast of Jacksonville, Florida.

\section{Discussion}

Despite the high diversity and ecological importance of squat lobsters worldwide, many of their ecological and evolutionary characteristics remain poorly known (Baba 2005). This is particularly true for the WA. Here, we report on the squat lobster species found in and around cold seep and CWC habitats from sites in the GOM and on the continental shelf and slope of the NWA. This study is the first to incorporate WA species of Munida into a phylogenetic framework. Four species of Munida were recorded from these locations. The species assemblage of Munidopsis was more diverse and included 
five species known to science and four putatively new species. Only one of these species, M. curvirostra, was included in previous phylogenetic studies. Eight species of Munidopsis were added to previous phylogenetic findings and dramatically increased the representation of WA species in these types of analyses.

\subsection{Munida}

Preliminary inferences regarding phylogeography of Munida were possible with the inclusion of WA species of Munida in our phylogenetic analysis. Previous phylogenetic studies of Munida that considered both COI and 16S (e.g. (Machordom and Macpherson 2004; Cabezas et al., 2011a) were concordant with the predominant patterns of relationships documented in this study. Generally, all Atlantic species have at least one close relative also from the Atlantic, but the three clades containing Atlantic species were scattered throughout the tree. These results provide several examples of phylogenetic association between the WA and its closest neighboring BGP, the NEA. A similar pattern of evolutionary relatedness between western and eastern Atlantic regions has been shown in other marine crustaceans (Aarbakke et al., 2014). However, Schnabel et al. (2011) found that WA squat lobster species assemblages were most similar to the Southeast Atlantic (SEA) and the Northeast Pacific (NEP) BGPs. Correlation between patterns of evolutionary relatedness and biogeographic proximity of species within and between the WA, SEA and NEP could not be examined in our analysis as no COI sequences of SEA or NEP munidid species were registered in Genbank. Increasing representation of WA species, as well as those from the SEA and NEP, in future phylogenetic analyses is imperative to our understanding of relationships between species assemblages and phylogenetic relatedness.

Similar to the findings of Machordom and Macpherson (2004) and Cabezas et al. (2011a), our phylogenetic results illustrate that more recent relationships have high support, but deeper, likely older relationships remain unresolved. High levels of polymorphism in COI could be indicative of a fast mutation rate within Munida. Alternatively, taxa may have been isolated for extended periods, allowing for mutations to accumulate. Nevertheless, assuming a standard animal mitochondrial divergence rate of 1-2\% per million years, Munida split from other galatheoid genera 7-14 million years ago (Machordom and Macpherson 2004). Increased sampling of Munida in future surveys with subsequent addition of genetic data in phylogenetic analyses as well as inclusion of slower-evolving mitochondrial and nuclear genes will lead to better resolution of deeper clades and divergence rates specific to Munididae. Thus, the accuracy and precision of estimations of species and genera divergences will increase. 
Despite uneven sampling between the NWA and GOM and small sample sizes, our results suggest minimal population differentiation for species of Munida between basins. In the three species collected in both the NWA and the GOM, haplotypes were shared between basins or were closely related. Similarly, Schnabel et al. (2011) biogeographic analysis did not distinguish between the GOM and NWA. Other species of Munida represent a range of haplotype patterns and levels of diversity, showing no uniform pattern of complexity or diversity. Munida gracilis collected from sites near New Zealand showed high levels of genetic diversity and complexity (Bors et al., 2012). In a network where more than one evolutionary path is possible between several haplotypes, 33 unique haplotypes were reported among 49 individuals. Interestingly, the remaining haplotypes were shared across sampling sites, indicating no biogeographic signal (Bors et al., 2012). Similar levels of diversity and lack of geographic population structure were observed in $M$. thoe. This species, reported from the Norfolk seamounts in the South West Pacific, shared 29 haplotypes among 35 individuals (Samadi et al., 2006). In contrast, M. gregaria (including M. subrugosa, recently placed in synonymy of M. gregaria) sampled from southern South America had a simple, star-shaped pattern of COI haplotype diversity and haplotypes were shared across sample sites (Pérez-Barros et al., 2008). This species also had the lowest haplotype diversity of all species of Munida analyzed in this study (Table 3). Similarly, two species collected from the Norfolk seamounts, had a single COI haplotype (M. acantha) or a dominant haplotype and a few closely-related rare haplotypes (M. zebra; Samadi et al., 2006). In the current study, both NWA species, M. iris and $M$. microphthalma, displayed complex haplotype network patterns (Figure 3) more like M. gracilis. The NWA species demonstrated groups of haplotypes separated by several unsampled mutational steps, as well as multiple pathways connecting haplotypes. Additional sampling may have recovered some of the missing, intermediate haplotypes. However, our sample size for M. iris $(\mathrm{N}=40)$ was larger than those reported in most other studies that did not reveal the same pattern as $M$. iris, suggesting that the divergence between haplotypes observed in $M$. iris was not due to sampling bias.

Overall, intraspecific diversity of NWA species was low (mean $0.7 \%$; range $(0.3 \%-1.3 \%)$ ) (Table 3) compared to other studies. Machordom and Macpherson (2004) reported mean intraspecific differentiation of COI sequences of $0.83 \%$ with a range from $0.00 \%$ to $14.00 \%$ within 36 species of Munida. However, the greatest genetic differentiation resulted from comparisons involving mis-identified cryptic species and comparisons with Munida callista, since reclassified as Babamunida callista (Cabezas et al., 2009). Inter-specific divergences mostly fell within the range, reported by Machordom and Machpherson (2004), between 36 species of Munida (3.50\% to 22.53\%). However, with the addition of NWA species, the observed lower bound of inter-specific genetic divergences decreased to $2.8 \%$ (M. iris 
vs. $M$. rutllanti) within the genus. The four NWA species of Munida in this study were more closely related to each other and to NEA taxa, according to our phylogenetic analyses.

Habitat characteristics that correspond to samples of Munida are rarely reported in the literature. Only two species of Munida have been reported from vent or seep habitats (Martin and Haney, 2005). Interestingly, Munida valida and M. sanctipauli, both collected near CWC sites, formed a closer relationship with each other than with M. microphthalma, which was the only species of Munida collected at cold seep sites and at lower slope depths. Collection and incorporation of habitat information in future studies will help elucidate the influence of habitat on ecological speciation in Munida.

\subsection{Munidopsis}

Munidopsis is a problematic genus taxonomically. Over 225 species have been described (Macpherson and Baba 2011) and many new species have been identified (e.g. Schnabel and Ahyong 2015). New information and better understanding of relationships often leads to synonymies and reclassifications (e.g. Ahyong 2014). Recent studies have increased our knowledge of morphology and phylogenetics of the genus Munidopsis (e.g. Jones and Macpherson 2007; Ahyong et al., 2011; Ahyong 2014). Few studies have incorporated species from the NWA. Our study adds a biogeographic perspective to the current knowledge of phylogenetic relationships within the genus Munidopsis through the addition of several NWA and GOM species, a region where genetic information was lacking. Only five (10\%) of the 48 known species from the NWA (Baba et al., 2008) were collected. Furthermore, we collected almost as many (4) putative new species, indicating that biodiversity estimates of squat lobsters in the NWA will continue to increase. Given that evolutionarily divergent yet sympatric lineages of Munidopsis co-occur, these results highlight the diversity of munidopsids at GOM cold seeps.

Chemosynthetic communities had more diverse assemblages of species of Munidopsis than those collected at CWC habitats. Only two species, Munidopsis sp. D and M. penescabra, were collected solely from coral sites. Phylogenetically, both of these species were positioned in one clade (Clade A, Figure 4), though they were not close relatives. Other WA species in Clade A included Munidopsis sp. C and M. curvirostra collected from both coral and seep sites, and Munidopsis sp. B, collected from two different GOM seep sites. Clearly, habitat utilization did not correlate with phylogenetic relatedness in this clade. 
All individuals within each of the putative new species (Munidopsis sp. A-D), formed monophyletic clades with their conspecifics in the phylogeny, lending evidence that these are true taxonomic groups. Three of these species (Munidopsis spp. B-D) belong to Clade A that contained species belonging to the M. serricornis species complex. Ahyong (2014) recently re-examined specimens previously identified as M. serricornis, considered a cosmopolitan species. The author restricted $M$. serricornis sensu stricto to the North Atlantic Ocean and identified six species from the Indian and Pacific oceans. One species from the $M$. serricornis complex, $M$. comarge, and another species, $M$. trifida, superficially close, morphologically, to species in the complex, occur in Clade A (Figure 4; Galathodes group, Ahyong et al., 2014). Munidopsis sp. D, collected from submarine canyons from the northeastern United States continental margin, showed genetic similarities to M. trifida. Munidopsis comarge and Munidopsis sp. C also fell within this clade, suggesting that one or both of these undescribed species may be part of the $M$. serricornis complex. To date, there are no DNA sequences from $M$. serricornis sensu stricto. Acquiring genetic information from the entire species complex would be valuable to future phylogenetic studies of Munidopsis.

In the predominantly chemosynthetic clade, (Clade B, Figure 4), many close phylogenetic associations between WA and NEP species of Munidopsis are hypothesized. Close relationships between WA and NEP species assemblages were also suggested by Schnabel et al. (2011) in their biogeographic analysis. Of the 18 species of Munidopsis in Clade B, only M. kensmithi, M. segonzaci, and M. tiburon have not been recorded from a chemosynthetic community. The NWA species, Munidopsis sp. A, M. livida, and M. similis, were ancestral to many of the species collected from hydrothermal vents, wood falls, and whale falls from the NEP and East Pacific Rise (EPR). These findings corroborate those presented by Jones and Macpherson (2007) whereby $M$. bracteosa belonged to a species complex that included $M$. recta, the most common species from the expansive EPR, $M$. scotti from the Juan de Fuca vent system, and M. exuta from the Mid-Atlantic Ridge. In fact, a 99\% sequence identity was found between Munidopsis sp. A from GOM seeps and M. bracteosa and M. antonii collected from the NEP (Jones and Macpherson 2007). Sequence divergence of approximately $1 \%$ suggests that these individuals may have relatively recent evolutionary connections (less than a million years applying the same rate calibration as above). These lineages may be in the process of speciating since several diagnostic morphological differences were identified. Alternatively, COI may have a slower mutation rate within certain clades of Munidopsis leading to gene trees that do not accurately reflect the evolutionary history of the species. Overall, Jones and Macpherson (2007) also observed a wide range of interspecific divergences in species of Munidopsis from the Pacific Ocean. Similar to our results, lower values of genetic distance did not necessarily correspond to species with the closest morphological resemblance. Conversely, some species 
exhibited low genetic differentiation, yet differed greatly morphologically. Therefore, species of Munidopsis have moderate to high levels of genetic divergence that do not correspond to geographic distance or morphological similarity.

Though genetic differences between different species of Munidopsis are generally moderate to large, genetic differentiation within species was low compared to patterns observed in Munida. Thaler et al. (2014) and Jones and Macpherson (2007) estimated intraspecific genetic differentiation in species of Munidopsis occurring at Pacific hydrothermal vent habitats and other NEP sites. Both studies revealed very small (typically less than one percent) haplotype diversities based on COI sequences, even for species with large geographic ranges. For example, 22 individuals of $M$. recta shared eight haplotypes across the entire expanse of the EPR (Jones and Macpherson 2007). Compared to other anomuran species, M. lauensis has a haplotype diversity value an order of magnitude lower than all other groups (Table 3). No haplotype diversity was observed in 23 individuals of $M$. polymorpha, a species endemic to anchialine caves of the Canary Islands (NEA; Cabezas et al., 2012). Therefore, putative signals of population differentiation, even those obtained from species with small sample sizes, are worth noting, considering the prevailing pattern of very low haplotype diversity and no genetic divergence within species of Munidopsis. For example, there appears to be a putative signal of genetic differentiation between the GOM and NWA individuals of Munidopsis sp. C and M. curvirostra. Three individuals of M. curvirostra collected from Norfolk Canyon were genetically identical to each other and to three specimens from the Gulf of St. Lawrence, Canada (Radulovici et al., 2009). A single M. curvirostra specimen from the GOM (this study) differed by four mutations from the NWA haplotype. These seven $M$. curvirostra individuals had as many mutational differences as 116 individuals of M. lauensis (Table 5). Munidopsis sp. C was collected in the GOM, with the exception of two specimens collected off the coast of Jacksonville, Florida (JAX; NWA). Both JAX individuals shared a haplotype two mutational steps away from its nearest genetic relative, and five steps away from the common haplotype (Figure 5). Nevertheless, increased sampling is warranted before concluding that a biogeographic barrier exists between NWA and GOM populations of these species.

Although two recently-discovered cold seep sites near Baltimore and Norfolk canyons were explored in 2012 and 2013 in conjunction with this study, no squat lobster species were observed, even though both seep sites were within the depth range of GOM seeps. Lack of squat lobsters at these newly discovered seeps was unusual considering that Munidopsis spp. were reported from a nearby methane seep on Blake Ridge, off the coast of South Carolina (Van Dover et al., 2003). Lack of predator/scavengers may be indicative of young, uncolonized chemosynthetic communities at mid-Atlantic sites. However, the extensive sampling of bathymodiolin mussels from many size classes suggests that the seep communities 
were established long enough for extensive mussel colonization and maturation. Brothers et al. (2013) reported evidence for extensive methane venting on the southeastern United States continental margin beyond Blake Ridge (Van Dover et al., 2003), but no seep-associated fauna were reported other than bivalves. Quattrini et al. (2015) explored three seep sites on the northeastern United States continental margin. Interestingly, one or two crustacean species were reported from each seep site, but no squat lobster species. Further explorations of putative cold seeps off the eastern coast of the United States is necessary to determine if cold seep sites other than Blake Ridge are devoid of squat lobsters, a taxon considered part of the dominant megafauna of other chemosynthetic communities.

Endemism of squat lobster species within chemosynthetic habitats is rare (Martin and Haney 2005; Macpherson and Segonzac 2005) with most taxa considered to be opportunistic generalists with diversified feeding habits (Lovrich and Thiel, 2011). Squat lobster species recorded strictly from chemosynthetic habitats are restricted to members of Kiwaidae (Chirostyloidea) (Macpherson et al., 2005; Thurber et al., 2011) and Shinkaia crosnieri (Munidopsidae) (Tsuchida et al 2003; Yang et al., 2016). The single species of Munida, M. microphthalma, collected at GOM deep chemosynthetic sites included in this analysis, is known from cold seep sites in the Barbados Accretionary Prism, as well as throughout the WA (Martin and Haney 2005; Baba et al., 2008). Several species of Munidopsis in our collections were collected from chemosynthetic communities in the GOM. However, all were known from nonchemosynthetic sites as well (Macpherson and Segonzac 2005). Two species, Munidopsis sp. C and M. curvirostra, were collected at GOM seep sites and NWA coral sites, further demonstrating the generalist nature of some munidopsids. Moreover, at seep site AC818, three different species, Munidopsis sp. A, M. bermudezi, and M. livida, were collected on the same dive, illustrating shared habitats among species and possible overlapping ecological niches.

Our phylogenetic analyses of Munida and Munidopsis are the most comprehensive analyses to date and include more species from the northwestern Atlantic than previously published studies. The WA exhibited the highest level of endemism for squat lobster species of the eight BGPs (Schnabel et al., 2011), yet this region is often the least represented in phylogenetic studies of squat lobsters. In our study, WA species were scattered throughout the phylogenies, indicating multiple evolutionary lineages in the WA province. This study found examples of close relationships between the WA and NEA within both squat lobster genera examined. Furthermore, phylogeographic affinities among NEP and WA species of Munidopsis were apparent, and the degree of divergence was higher when comparing the WA species to those from the West Pacific; both patterns agree with the biogeographic hypotheses set forth by Schnabel et al. (2011). Although Munidopsis Clade B was comprised predominantly of species collected from various 
chemosynthetic communities, WA species collected from cold seeps habitats were also found in Clade A. Therefore, habitat does not fully explain phylogenetic relationships.

The diversity of galatheoid crabs was high at these extraordinary deep-sea environments in the NWA, though still much lower than the SWP. We are just beginning to recognize this diversity. Collections are key to our understanding of the morphology, taxonomy, and ecology of this group. Most of these species cannot be identified from photographs or videos. Once we are able to positively identify the galatheoid fauna associated with cold seep and cold-water coral environments, we can utilize this information to make progress on the systematics, phylogenetics, phylogeography and connectivity of the members of this group. We have made significant progress toward this goal, but more intensive sampling is needed to determine the total diversity of, and the evolutionary relationships between the galatheoid crab species inhabiting NWA and GOM deep-sea communities. 


\section{Acknowledgements}

This project has been financially supported by the USGS Outer Continental Shelf Ecosystem Program and was sponsored by the Bureau of Ocean Energy Management (BOEM) and NOAA through National Oceanographic Partnership Program projects. NOAA-Office of Ocean Exploration and Research sponsored several research cruises that resulted in samples from the NWA (grants to Steve Ross, Sandra Brooke, Martha Nizinski, lead PIs). Two R/V Cape Hatteras missions were sponsored by the DUKE/UNC Ocean Consortium (grants to S. Ross). Thanks to the crew of all research vessels listed in Table 1 caption and S. Ross, S. Brooke, Greg Boland, Liz Baird, Jennifer McClain-Counts, Amanda Demopoulos. Thanks to Kevin Grimes, Lakyn Sanders and Robin Johnson for laboratory help and Erik Cordes and Charles Fisher for providing samples. Any use of trade, firm, or product names is for descriptive purposes only and does not imply endorsement by the U.S. Government. 


\section{References}

Aarbakke ONS, Bucklin A, Halsband C, Norrbin F (2014) Comparative phylogeography and demographic history of five sibling species of Pseudocalanus (Copepoda: Calanoida) in the North Atlantic Ocean. J Exp Mar Biol Ecol 461:479-488.

Ahyong ST (2014) Deep-sea Squat Lobsters of the Munidopsis serricornis Complex in the Indo-West Pacific, with Descriptions of Six New Species (Crustacea: Decapoda: Munidopsidae). Rec Aust Mus 66 (3):197-216.

Ahyong ST, Andreakis N, Taylor J (2011) Mitochondrial phylogeny of the deep-sea squat lobsters, Munidopsidae (Galatheoidea). Zoologischer Anzeiger - A Journal of Comparative Zoology 250 (4):367-377.

Baba K (2005) Deep-sea chirostylid and galatheid crustaceans Decapoda: Anomura from the Indo-Pacific, with a list of species. Galathea Report v. 20, p. 5-317

Baba K, Ahyong ST, Macpherson E (2011) Morphology of marine squat lobsters. In: Poore GCB, Ahyong ST, Taylor J (eds) The Biology of Squat Lobsters. CRC Press, Boca Raton, FL, pp 1-38

Baba K, Macpherson E, Poore GCB, Ahyong ST, Bermudez A, Cabezas P, Lin CW, Nizinski M, Rodrigues C, Schnabel KE (2008) Catalogue of squat lobsters of the world (Crustacea: Decapoda: Anomura - families Chirostylidae, Galatheidae and Kiwaidae). Zootaxa (1905):1-220

Bandelt HJ, Forster P, Rohl A (1999) Median-joining networks for inferring intraspecific phylogenies. Molecular Biology and Evolution 16 (1):37-48

Bergquist DC, Ward T, Cordes EE, McNelis T, Howlett S, Kosoff R, Hourdez S, Carney R, Fisher CR (2003) Community structure of vestimentiferan-generated habitat islands from Gulf of Mexico cold seeps. J Exp Mar Biol Ecol 289 (2):197-222.

Bors EK, Rowden AA, Maas EW, Clark MR, Shank TM (2012) Patterns of Deep-Sea Genetic Connectivity in the New Zealand Region: Implications for Management of Benthic Ecosystems. Plos One 7 (11):16pp

Brooke S, Ross SW (2014) First observations of the cold-water coral Lophelia pertusa in mid-Atlantic canyons of the USA. Deep-Sea Res Pt Ii 104:245-251.

Brothers LL, Van Dover CL, German CR, Kaiser CL, Yoerger DR, Ruppel CD, Lobecker E, Skarke AD, Wagner JKS (2013) Evidence for extensive methane venting on the southeastern U.S. Atlantic margin. Geology 41 (7):807-810.

Cabezas P, Alda F, Macpherson E, Machordom A (2012) Genetic characterization of the endangered and endemic anchialine squat lobster Munidopsis polymorpha from Lanzarote (Canary Islands): management implications. Ices J Mar Sci 69 (6):1030-1037

Cabezas P, Lin CW, Chan TY (2011a) Two new species of the deep-sea squat lobster genus Munida Leach, 1820 (Crustacea: Decapoda: Munididae) from Taiwan: morphological and molecular evidence. Zootaxa (3036):26-38

Cabezas P, Macpherson E, Machordom A (2009) Morphological and molecular description of new species of squat lobster (Crustacea: Decapoda: Galatheidae) from the Solomon and Fiji Islands (SouthWest Pacific). Zoological Journal of the Linnean Society 156 (3):465-493

Cabezas P, Macpherson E, Machordom A (2011b) Allogalathea (Decapoda: Galatheidae): a monospecific genus of squat lobsters? Zoological Journal of the Linnean Society 162(2):245 - 270

Carney RS (1994) Consideration of the oasis analogy for the chemosynthetic communities at Gulf of Mexico hydrocarbon vents. Geo-Marine Letters 14:149-159

Chevaldonné P, Olu K (1996) Occurrence Of Anomuran Crabs (Crustacea: Decapoda) In Hydrothermal Vent And Cold-Seep Communities: A Review. P Biol Soc Wash 109

Cordes EE, Becker EL, Hourdez S, Fisher CR (2010) Influence of foundation species, depth, and location on diversity and community composition at Gulf of Mexico lower-slope cold seeps. Deep-Sea Research II 57: 1870-1881.

Cordes EE, Bergquist DC, Fisher CR (2009) Macro-Ecology of Gulf of Mexico Cold Seeps. Annual Review of Marine Science 1 (1):143-168. 
Cordes EE, Bergquist DC, Predmore BL, Jones C, Deines P, Telesnicki G, Fisher CR (2006) Alternate unstable states: Convergent paths of succession in hydrocarbon-seep tubeworm-associated communities. J Exp Mar Biol Ecol 339 (2):159-176.

Cordes EE, Carney SL, Hourdez S, Carney RS, Brooks JM, Fisher CR (2007) Cold seeps of the deep Gulf of Mexico: Community structure and biogeographic comparisons to Atlantic equatorial belt seep communities. Deep-Sea Res Pt I 54 (4):637-653.

Cordes EE, Hourdez S, Predmore,BL, Redding ML, Fisher CR (2005). Succession of hydrocarbon seep communities associated with the long-lived foundation species Lamellibrachia luymesi. Marine Ecology Progress Series 305: 17-29.

Cordes EE, McGinley MP, Podowski EL, Becker EL, Lessard-Pilon S, Viada ST, Fisher CR (2008) Coral communities of the deep Gulf of Mexico. Deep-Sea Research I 55:777-787.

Costa FO, deWaard JR, Boutillier J, Ratnasingham S, Dooh RT, Hajibabaei M, Hebert PDN (2007) Biological identifications through DNA barcodes: the case of the Crustacea. Can J Fish Aquat Sci 64 (2):272-295

Cubelio SS, Tsuchida S, Hendrickx ME, Kado R, Watanabe S (2007) A new species of vent associated Munidopsis (Crustacea : Decapoda : Anomura : Galatheidae) from the Western Pacific, with notes on its genetic identification. Zootaxa (1435):25-36

da Silva JM, Creer S, dos Santos A, Costa AC, Cunha MR, Costa FO, Carvalho GR (2011) Systematic and Evolutionary Insights Derived from mtDNA COI Barcode Diversity in the Decapoda (Crustacea: Malacostraca). Plos One 6 (5):15pp

Demopoulos AW, Bourque JR, Brooke S, Ross SW (2014) Benthic Community Structure at Newly Investigated Hydrocarbon Seeps on the Continental Slope of the Western North Atlantic. (Ocean Sciences Meeting, 2014).

Felder DL, Alvarez F, Goy JW, Lemaitre R (2009) Decapoda (Crustacea) of the Gulf of Mexico, with comments on the Amphionidacea, vol 1. Gulf of Mexico Origin, Waters, and Biota, Volume 1, Biodiversity. Texas A\&M University Press, College Station, TX

Folmer O, Black M, Hoeh W, Lutz RA, Vrijenhoek RC (1994) DNA primers for amplification of mitochondrial cytochrome c oxidase subunit I from diverse metazoan invertebrates. Mol Mar Biol Biotech 3 (5):294-299

Garcia-Merchan VH, Robainas-Barcia A, Abello P, Macpherson E, Palero F, Garcia-Rodriguez M, de Sola LG, Pascual M (2012) Phylogeographic patterns of decapod crustaceans at the AtlanticMediterranean transition. Mol Phylogenet Evol 62 (2):664-672

Gelman A, Rubin DB (1992) Inference from Iterative Simulation Using Multiple Sequences. Statistical Science 7 (4):457-472

Haye PA, Salinas P, Acuña E, Poulin E (2010) Heterochronic phenotypic plasticity with lack of genetic differentiation in the southeastern Pacific squat lobster Pleuroncodes monodon. Evolution \& Development 12 (6):628-634

Hebert PDN, Cywinska A, Ball SL, DeWaard JR (2003) Biological identifications through DNA barcodes. P Roy Soc B-Biol Sci 270 (1512):313-321

Huelsenbeck JP, Ronquist F (2001) MRBAYES: Bayesian inference of phylogenetic trees. Bioinformatics 17 (8):754-755

Jones WJ, Macpherson E (2007) Molecular phylogeny of the east pacific squat lobsters of the genus Munidopsis (Decapoda : Galatheidae) with the descriptions of seven new species (vol 27, pg 477, 2007). Journal of Crustacean Biology 27 (4):698-698

Librado P, Rozas J (2009) DnaSP v5: a software for comprehensive analysis of DNA polymorphism data. Bioinformatics 25 (11):1451-1452.

Lin CW, Tsuchida S, Lin S, Berndt C, Chan TY (2013) Munidopsis lauensis Baba \& de Saint Laurent, 1992 (Decapoda, Anomura, Munidopsidae), a newly recorded squat lobster from a cold seep in Taiwan. Zootaxa 3737 (1):92-96 
Lovrich GA, Thiel M (2011) Ecology, physiology, feeding and trophic role of squat lobsters. In: Poore GCB, Ahyong ST, Taylor J (eds) The Biology of Squat Lobsters. CRC Press, Boca Raton, FL, $183-222$

MacDonald IR, Boland GS, Baker JS, Brooks JM, Kennicutt MC, Bidigare RR (1989) Gulf of Mexico hydrocarbon seep communities. Mar Biol 101 (2):235-247.

Machordom A, Macpherson E (2004) Rapid radiation and cryptic speciation in squat lobsters of the genus Munida (Crustacea, Decapoda) and related genera in the South West Pacific: molecular and morphological evidence. Mol Phylogenet Evol 33 (2):259-279

Macpherson E, Baba K (2011) Taxonomy of squat lobsters. In: Poore GCB, Ahyong ST, Taylor J (eds) The Biology of Squat Lobsters. CRC Press, Boca Raton, FL, pp 39-72

Macpherson E, de Forges BR, Schnabel K, Samadi S, Boisselier MC, Garcia-Rubies A (2010) Biogeography of the deep-sea galatheid squat lobsters of the Pacific Ocean. Deep-Sea Res Pt I 57 (2):228-238

Macpherson E, Jones W, Segonzac M (2005) A new squat lobster family of Galatheoidea (Crustacea, Decapoda, Anomura) from the hydrothermal vents of the Pacific-Antarctic Ridge. Zoosystema 27 (4):709-723

Macpherson E, Machordom A (2005) Use of morphological and molecular data to identify three new sibling species of the genus Munida Leach, 1820 (Crustacea, Decapoda, Galatheidae) from New Caledonia. J Nat Hist 39 (11):819-834.

Macpherson E, Segonzac M (2005) Species of the genus Munidopsis (Crustacea, Decapoda, Galatheidae) from the deep Atlantic Ocean, including cold-seep and hydrothermal vent areas. Zootaxa (1095):3-60

Martin JW, Haney TA (2005) Decapod crustaceans from hydrothermal vents and cold seeps: a review through 2005. Zoological Journal of the Linnean Society 145 (4):445-522

Nylander JAA, Wilgenbusch JC, Warren DL, Swofford DL (2008) AWTY (are we there yet?): a system for graphical exploration of MCMC convergence in Bayesian phylogenetics. Bioinformatics 24 (4):581-583.

O'Hara TD, Rowden AA, Williams A (2008). Cold-water coral habitats on seamounts: do they have a specialist fauna? Diversity and Distributions 14: 925-934.

Paull CK, Hecker B, Commeau R, R.P. F-L, Neumann C, Corso WP, Golubic S, Hook JE, Sikes E, Curray J (1984) Biological communities at the Florida escarpment resemble hydrothermal vent taxa. Science 226:965-967

Pérez-Barros P, D'Amato ME, Guzman NV, Lovrich GA (2008) Taxonomic status of two South American sympatric squat lobsters, Munida gregaria and Munida subrugosa (Crustacea : Decapoda : Galatheidae), challenged by DNA sequence information. Biol J Linn Soc 94 (2):421-434

Pérez-Barros P, Lovrich GA, Calcagno JA, Confalonieri VA (2014) Is Munida gregaria (Crustacea: Decapoda: Munididae) a truly transpacific species? Polar Biology 37 (10):1413-1420

Polzin T, Daneshmand SV (2003) On Steiner trees and minimum spanning trees in hypergraphs. Oper Res Lett 31 (1):12-20.

Quattrini AM, Nizinski MS, Chaytor JD, Demopoulos AWJ, Roark EB, France SC, Moore JA, Heyl T, Auster PJ, Kinlan B, Ruppel C, Elliott KP, Kennedy BRC, Lobecker E, Skarke A, Shank TM (2015) Exploration of the Canyon-Incised Continental Margin of the Northeastern United States Reveals Dynamic Habitats and Diverse Communities. Plos One 10 (10):e0139904.

Radulovici AE, Sainte-Marie B, Dufresne F (2009) DNA barcoding of marine crustaceans from the Estuary and Gulf of St Lawrence: a regional-scale approach. Mol Ecol Resour 9:181-187

Rambaut A . (2014) FigTree v1.4.2http://tree.bio.ed.ac.uk/software/figtree/

Rambaut A, Suchard MA, Xie D, Drummond AJ (2014) Tracer v1.6, Available from http://beast.bio.ed.ac.uk/Tracer

Raupach MJ, Barco A, Steinke D, Beermann J, Laakmann S, Mohrbeck I, Neumann H, Kihara TC, Pointner K, Radulovici A, Segelken-Voigt A, Wesse C, Knebelsberger T (2015) The Application 
of DNA Barcodes for the Identification of Marine Crustaceans from the North Sea and Adjacent Regions. Plos One 10 (9):23pp.

Reed JK, Ross SW (2005) Deep-water reefs off the southeastern U.S.:Recent discoveries and research. Journal of Marine Education 21 (4):33-37

Reed JK, Weaver DC, Pomponi SA (2006) Habitat and fauna of deep-water Lophelia pertusa coral reefs off the southeastern US: Blake Plateau, Straits of Florida, and Gulf of Mexico. B Mar Sci 78 (2):343-375

Roberts HH, Fisher CR, Brooks JM, Bernard B, Carney RS, Cordes E, Shedd W, Hunt J Jr, Joye S, MacDonald IR, Morrison CL (2007) Exploration of the deep Gulf of Mexico slope using DSV Alvin: Site selection and geologic character: Gulf Coast Association of Geological Societies Transactions, v. 57, p. 647-659

Rogers A (2004) The Biology, Ecology, and Vulnerability of Deep-Water Coral Reefs. International Union for Conservation of Nature and Natural Resources. https://cmsdata.iucn.org/downloads/alexrogers_cbdcop7_deepwatercorals_complete.pdf

Ronquist F, Huelsenbeck JP, Teslenko M (2011) Draft MrBayes version 3.2 Manual: Tutorials and Model Summaries. http://mrbayes.sourceforge.net/.

Roterman CN, Copley JT, Linse KT, Tyler PA, Rogers AD (2013) The biogeography of the yeti crabs (Kiwaidae) with notes on the phylogeny of the Chirostyloidea (Decapoda: Anomura). P Roy Soc B-Biol Sci 280 (1764): 9pp.

Samadi S, Bottan L, Macpherson E, Forges B, Boisselier M-C (2006) Seamount endemism questioned by the geographic distribution and population genetic structure of marine invertebrates. Mar Biol 149 (6): $1463-1475$

Schnabel KE, Ahyong ST (2015) Two new species of Munidopsis (Crustacea: Anomura: Munidopsidae) from the Kermadec and Louisville ridge systems off New Zealand. Zootaxa 3995 (1):241

Schnabel KE, Cabezas P, McCallum A, Macpherson E, Ahyong ST, Baba K (2011) Worldwide distribution patterns of squat lobsters. In: Poore GCB, Ahyong ST, Taylor J (eds) The Biology of Squat Lobsters. CRC Press, Boca Raton, FL, 149-182

Skarke A, Ruppel C, Kodis M, Brothers D, Lobecker E (2014) Widespread methane leakage from the sea floor on the northern US Atlantic margin. Nat Geosci 7 (9):657-661

Stoeckle M (2003) Taxonomy, DNA, and the bar code of life. Bioscience 53 (9):796-797.

Tamura K (1992) Estimation of the number of nucleotide substitutions when there are strong transitiontransversion and G+C-content biases. Molecular Biology and Evolution 9 (4):678-687

Tamura K, Stecher G, Peterson D, Filipski A, Kumar S (2013) MEGA6: Molecular Evolutionary Genetics Analysis Version 6.0. Molecular Biology and Evolution 30 (12):2725-2729.

Tavaré S (1986) Some probabilistic and statisical problems on the analysis of DNA sequences. In: Miura RM (ed) Some mathematical questions in biology: DNA sequence analysis, vol 17. Lecture on Mathematics in the Life Sciences. The American Mathematical Society, Providence, RI., pp 57-86

Thaler AD, Plouviez S, Saleu W, Alei F, Jacobson A, Boyle EA, Schultz TF, Carlsson J, Van Dover CL (2014) Comparative Population Structure of Two Deep-Sea Hydrothermal-Vent-Associated Decapods (Chorocaris sp 2 and Munidopsis lauensis) from Southwestern Pacific Back-Arc Basins. Plos One 9 (7):13pp.

Thurber AR, Jones WJ, Schnabel K (2011) Dancing for Food in the Deep Sea: Bacterial Farming by a New Species of Yeti Crab. Plos One 6 (11)12pp.

Tsuchida S, Fujiwara Y, Fujikura K (2003) Distribution and Population Structure of the Galatheid Crab Shinkaia crosnieri (Decapoda: Anomura: Galatheidae) in the Southern Okinawa Trough. Japanese journal of benthology 58:84-88.

Turnipseed M, Knick KE, Lipcius RN, Dreyer J, Van Dover CL (2003) Diversity in mussel beds at deepsea hydrothermal vents and cold seeps. Ecol Lett 6:518-523

Van Dover CL, Aharon P, Bernhard JM, Caylor E, Doerries M, Flickinger W, Gilhooly W, Goffredi SK, Knick KE, Macko SA, Rapoport S, Raulfs EC, Ruppel C, Salerno JL, Seitz RD, Sen Gupta BK, 
Shank T, Turnipseed M, Vrijenhoek R (2003) Blake Ridge methane seeps: characterization of a soft-sediment, chemo synthetically based ecosystem. Deep-Sea Res Pt I 50 (2):281-300.

Wilgenbusch J.C., Warren D.L., Swofford D.L. 2004. AWTY: A system for graphical exploration of MCMC convergence in Bayesian phylogenetic inference.http://ceb.csit.fsu.edu/awty.

Yang C-H, Tsuchida S, Fujikura K, Fujiwara Y, Kawato M, Chan T-Y (2016) Connectivity of the squat lobsters Shinkaia crosnieri (Crustacea: Decapoda: Galatheidae) between cold seep and hydrothermal vent habitats. B Mar Sci 92 (1):17-31.

Yang J-S, Yang W-J (2008) The complete mitochondrial genome sequence of the hydrothermal vent galatheid crab Shinkaia crosnieri (Crustacea: Decapoda: Anomura): A novel arrangement and incomplete tRNA suite. Bmc Genomics 9 (1):13pp. 


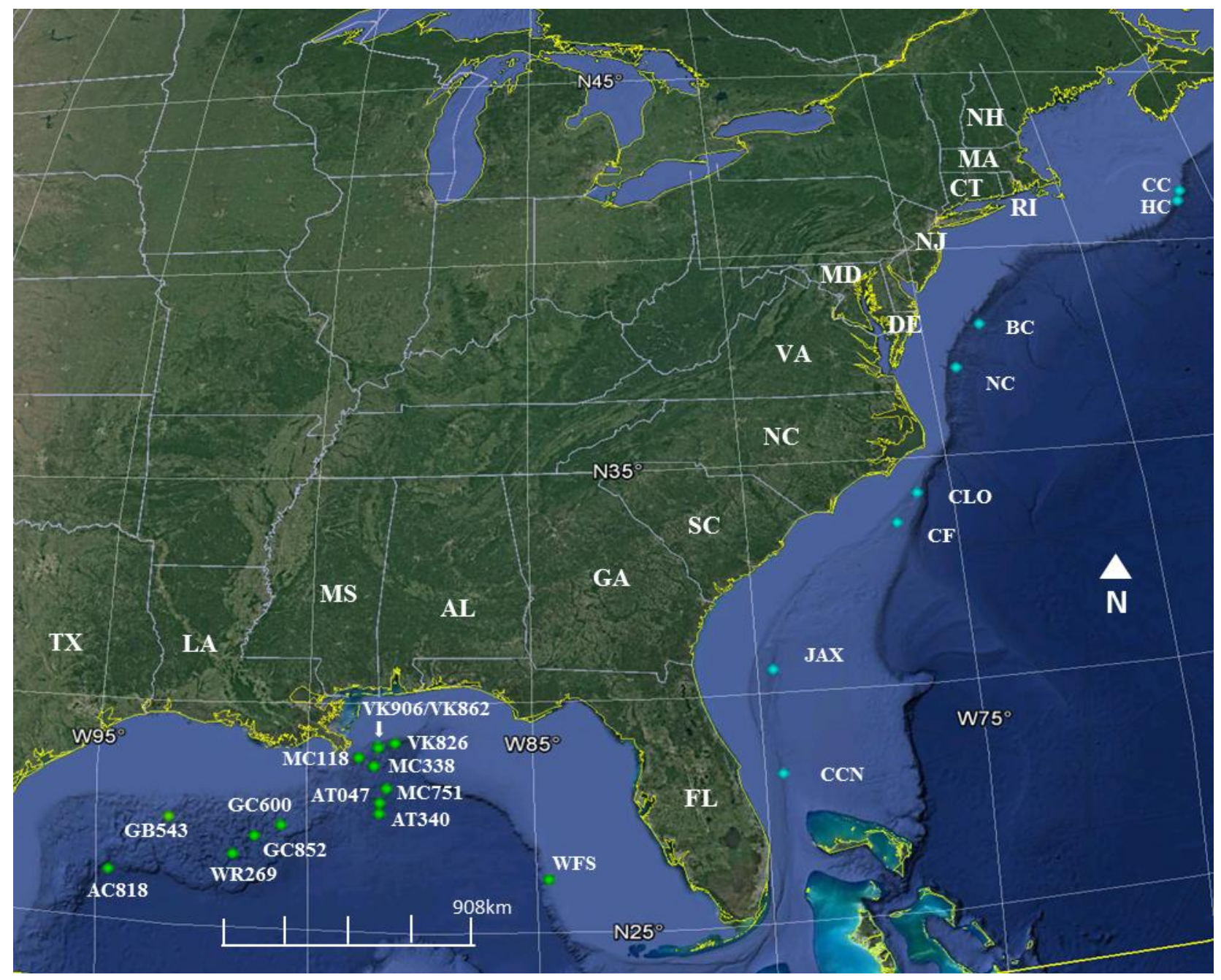

FIGURE 1: Map of Northwestern Atlantic (NWA) and Gulf of Mexico (GOM) sampling sites of Munida and Munidopsis. NWA sites shown as light blue, GOM shown as green. See Table 1 for site abbreviations. 


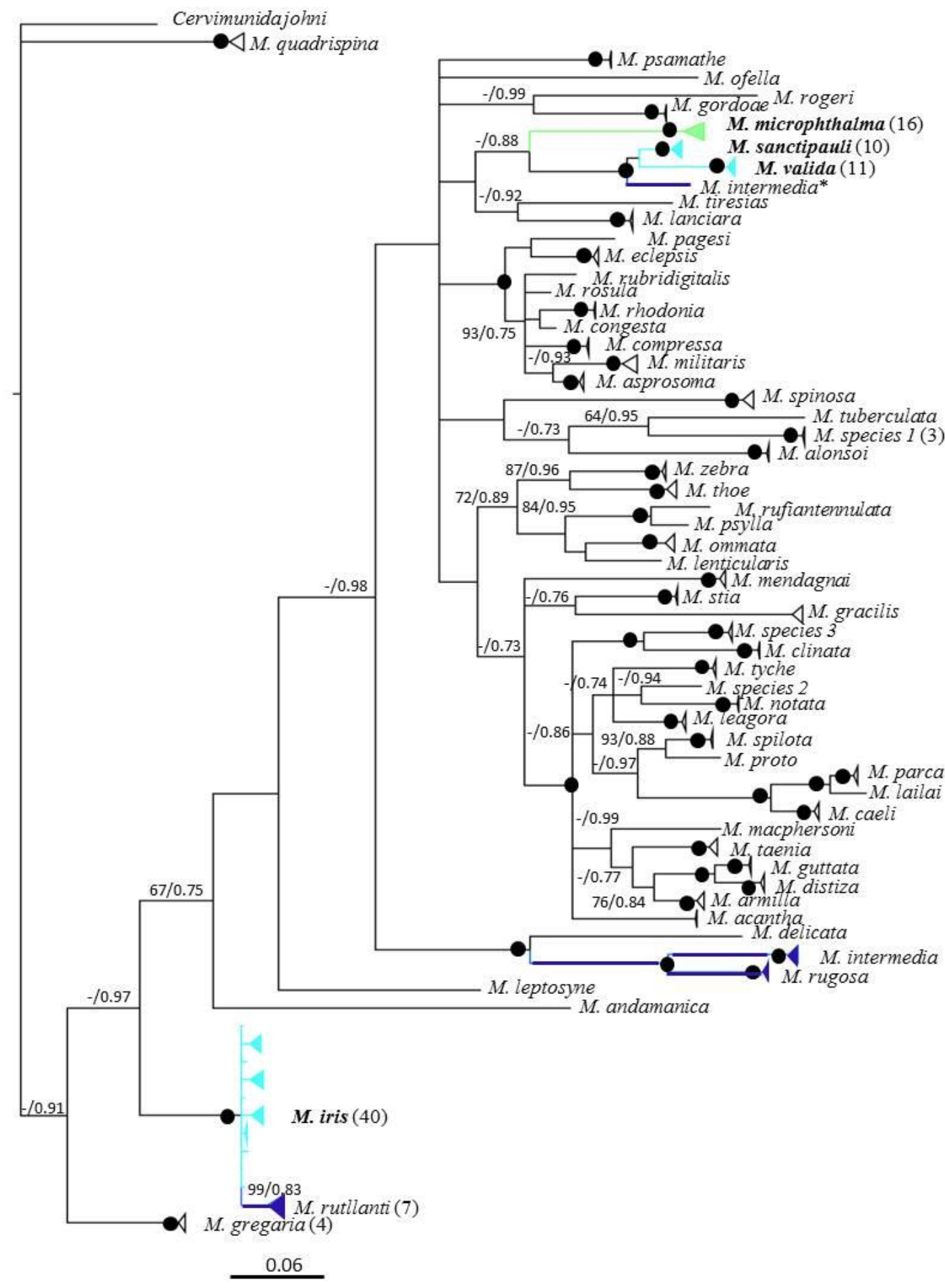

FIGURE 2: Bayesian phylogram of Munida based upon partial COI sequences. Branch colors represent oceanic regions from which taxon/sample originated: green $=\mathrm{GOM}$, dark blue $=$ NEA, aqua $=$ NWA + GOM; Taxa in bold were collected in this study. Collapsed clades (triangles) represent 2 sequences, unless otherwise noted by the number of sequences in parentheses. Black 
circles at nodes indicate non-parametric bootstrap support (maximum likelihood) and posterior probabilities (Bayesian inference) of $\geq 90 \%$ and $\geq 0.95$, respectively. Also indicated are support values $\geq 60 \%$ and/or $\geq 0.70$ for bootstrap and posterior probabilities, respectively. Scale bar denotes number of nucleotide substitutions per site. ${ }^{*} M$. intermedia JQ348884 

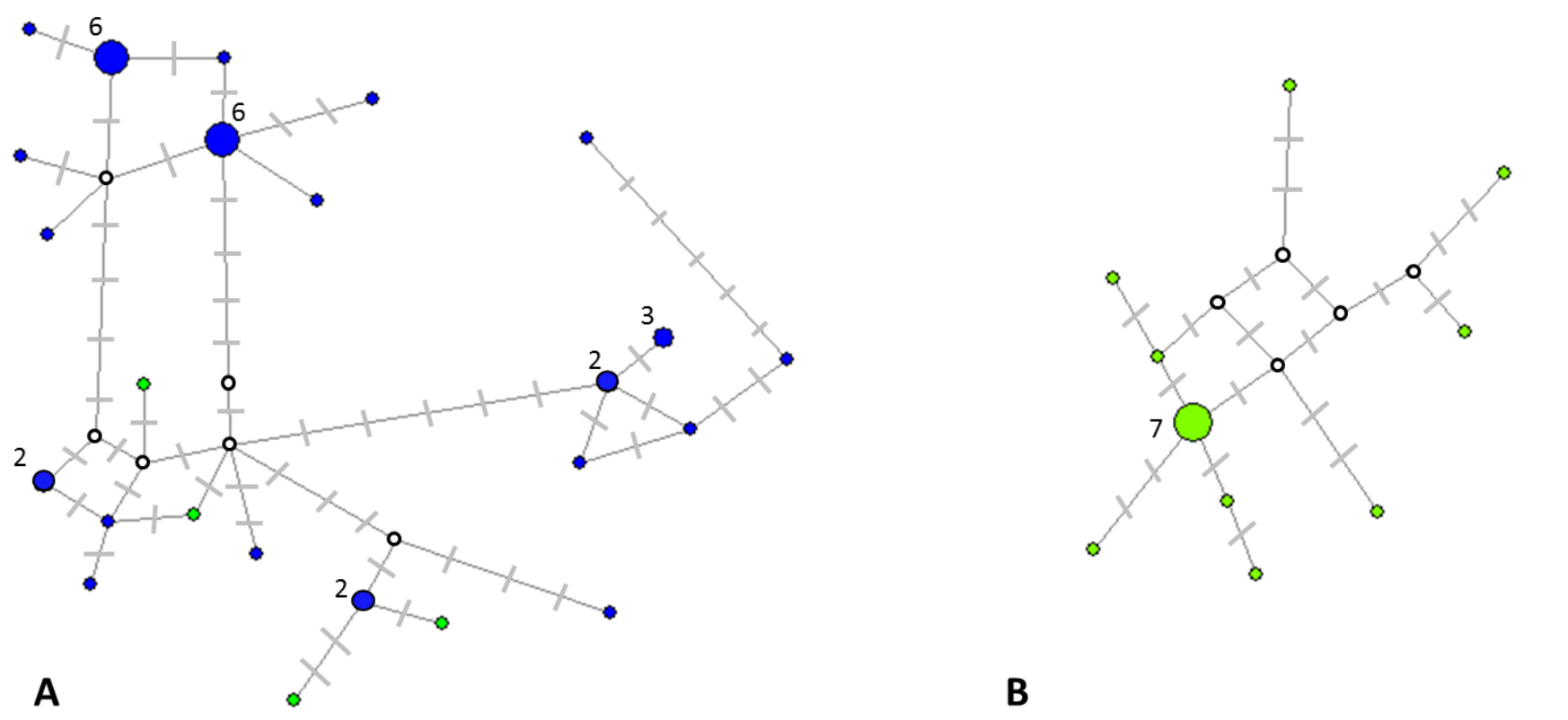

FIGURE 3: Median joining networks of COI haplotypes. A) Munida iris, $\mathrm{N}=37$ and B) Munida microphthalma, $\mathrm{N}=16$. Colored circles represent unique COI haplotypes. Number of individuals if $>1$ are indicated next to the haplotype. Sampling locations parsed by ocean basin; NWA = blue =; GOM = green. Hash marks are mutational steps between haplotypes. Open circles are inferred haplotypes. (Network v 4.6.1.3, Flexus Technology, Ltd) 


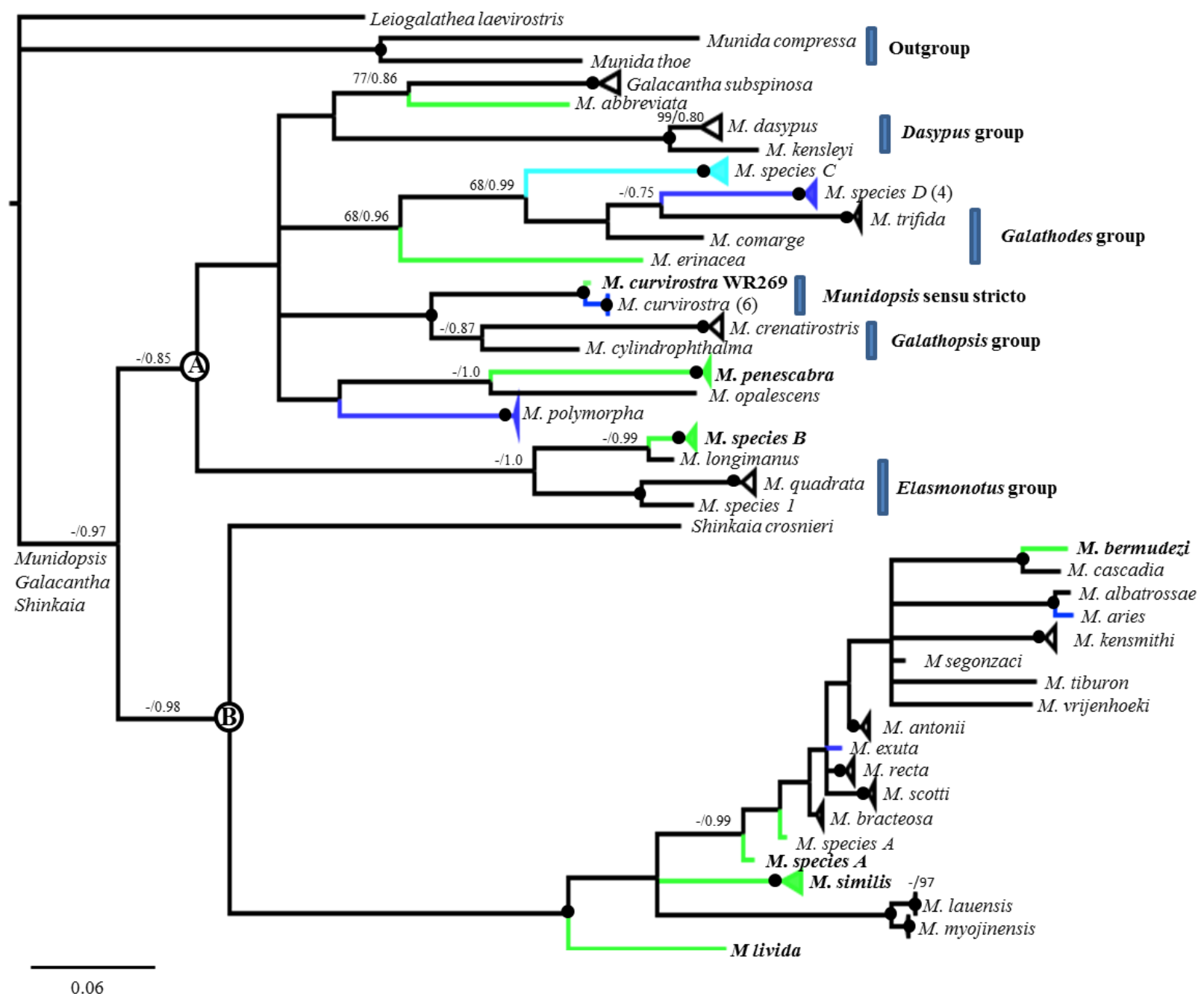

FIGURE 4: Bayesian phylogram of Munidopsidae based upon partial COI sequences. (A) and (B) denote two major well-supported clades. Branch colors represent oceanic regions: Green $=\mathrm{GOM}$, dark blue = northern Atlantic, excluding GOM, Aqua=NWA + GOM; Taxa in bold were collected in this study. Collapsed clades (triangles) represent 2 sequences, unless otherwise noted by the number of sequences in parentheses. Black circles at nodes indicate non-parametric bootstrap support (maximum likelihood) and posterior probabilities (Bayesian inference) of $\geq 90 \%$ and 0.95 , respectively. Also indicated are support values $\geq 60 \%$ and 0.70 for bootstrap and posterior probabilities, respectively. Scale bar denotes number of nucleotide substitutions per site Vertical blue bars indicate major morphological groups as in Ahyong et al (2011). 


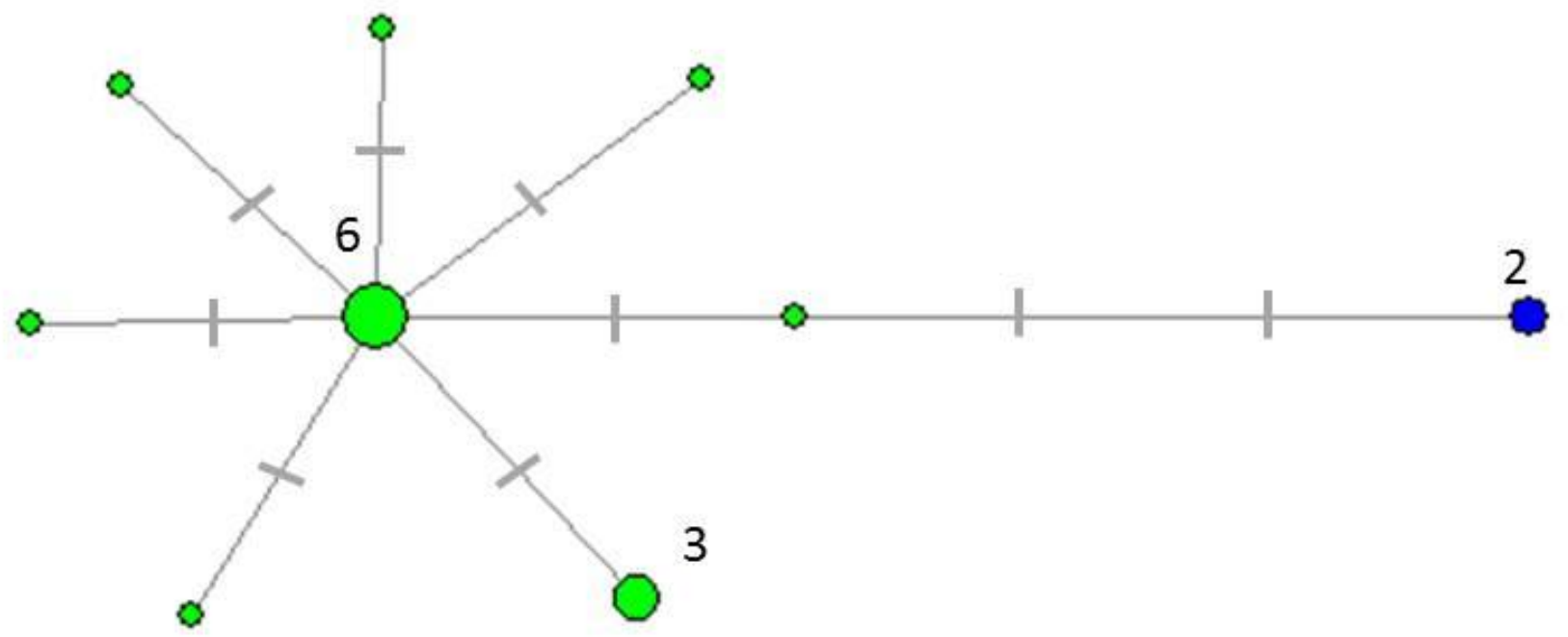

FIGURE 5: Median joining network of COI haplotypes for Munidopsis sp C, N=17. Colored circles represent unique COI haplotypes. Number of individuals if $>1$ are indicated next to the haplotype. Sampling locations parsed by ocean basin; $\mathrm{NWA}=$ blue $=; \mathrm{GOM}=$ green. Hash marks are mutational steps between haplotypes. (Network v 4.6.1.3, Flexus Technology, Ltd) 
TABLE 1: Sampling information for specimens of Munida and Munidopsis analyzed in this study. Individuals with bolded taxon names were collected from cold seep sites. Non-bolded taxa were collected from CWC sites.

\begin{tabular}{|c|c|c|c|c|c|c|c|c|c|}
\hline Taxon & Basin & Site $^{1}$ & $N$ & Sample code & Depth $(\mathrm{m})^{2}$ & $\begin{array}{l}\text { Latitude } \\
(\mathrm{N})^{2}\end{array}$ & $\begin{array}{l}\text { Longitude } \\
(\mathrm{W})^{2}\end{array}$ & Year & Ship/Sampling method ${ }^{3}$ \\
\hline Munida iris & NWA & $\mathrm{NC}$ & 5 & $\begin{array}{l}\text { MAC602, 604- } \\
07\end{array}$ & $255-270$ & $\begin{array}{l}37^{\circ} 04.256^{\prime}- \\
37^{\circ} 05.223^{\prime}\end{array}$ & $\begin{array}{l}74^{\circ} 34.262^{\prime}- \\
74^{\circ} 33.735^{\prime}\end{array}$ & 2013 & Ronald H. Brown/OT \\
\hline Munida iris & NWA & $\mathrm{NC}$ & 5 & $\begin{array}{l}\text { MAC603, 608- } \\
10,612\end{array}$ & $180-185$ & $\begin{array}{l}37^{\circ} 04.521^{\prime}- \\
37^{\circ} 05.614^{\prime}\end{array}$ & $\begin{array}{l}74^{\circ} 34.514^{\prime}- \\
74^{\circ} 34.095^{\prime}\end{array}$ & 2013 & Ronald H. Brown/OT \\
\hline Munida iris & NWA & $\mathrm{NC}$ & 22 & MAC207A-V & $160-165$ & $\begin{array}{l}37^{\circ} 05.041^{\prime}- \\
37^{\circ} 05.949^{\prime}\end{array}$ & $\begin{array}{l}74^{\circ} 34.445^{\prime}- \\
74^{\circ} 34.131^{\prime}\end{array}$ & 2013 & Ronald H. Brown/OT \\
\hline Munida iris & NWA & $\mathrm{BC}$ & 4 & MAC026-029 & $375-379$ & $38^{\circ} 07.468^{\prime}$ & $73^{\circ} 48.275^{\prime}$ & 2012 & Nancy Foster/K2 \\
\hline Munida cf. iris & GOM & VK906 & 3 & $\begin{array}{l}\text { CH10_118,120,1 } \\
21\end{array}$ & $401-435$ & $\begin{array}{l}29^{\circ} 04.350^{\prime}- \\
29^{\circ} 04.496^{\prime}\end{array}$ & $\begin{array}{l}88^{\circ} 22.975^{\prime}- \\
88^{\circ} 22.699^{\prime}\end{array}$ & 2010 & Cape Hatteras/K2 \\
\hline Munida cf. iris & GOM & VK826 & 1 & CH10_001 & $454-520$ & $\begin{array}{l}29^{\circ} 09.710^{\prime}- \\
29^{\circ} 09.720^{\prime}\end{array}$ & $\begin{array}{l}88^{\circ} 00.618^{\prime}, \\
88^{\circ} 01.269^{\prime}\end{array}$ & 2010 & Cape Hatteras/K2 \\
\hline Munida microphthalma & GOM & GC852 & 1 & 4186_01 & 1410 & $27^{\circ} 06.357^{\prime}$ & $91^{\circ} 09.974^{\prime}$ & 2006 & Atlantis/Alvin \\
\hline Munida microphthalma & GOM & GC600 & 3 & 4184_01-03 & 1250 & $27^{\circ} 21.991$ & $90^{\circ} 33.835^{\prime}$ & 2006 & Atlantis/Alvin \\
\hline Munida microphthalma & GOM & GC600 & 1 & 4174_02 & 1250 & $27^{\circ} 22.123$ & $90^{\circ} 33.982^{\prime}$ & 2006 & Atlantis/Alvin \\
\hline Munida microphthalma & GOM & GC852 & 3 & CH07_27_01-03 & $1426-1564$ & $27^{\circ} 06.3^{\prime *}$ & $91^{\circ} 09.9^{\prime} *$ & 2007 & Cape Hatteras/OT \\
\hline Munida microphthalma & GOM & GC852 & 1 & CH07_42_01 & $1478-1574$ & $27^{\circ} 06.3^{\prime} *$ & $91^{\circ} 09.9^{\prime} *$ & 2007 & Cape Hatteras/OT \\
\hline $\begin{array}{l}\text { Munida cf. } \\
\text { microphthalma }\end{array}$ & GOM & MC338 & 5 & LII10_2170-74 & 1374 & $28^{\circ} 67.508^{\prime}$ & $88^{\circ} 48.130^{\prime}$ & 2010 & Ronald H. Brown/J2 \\
\hline
\end{tabular}




\begin{tabular}{|c|c|c|c|c|c|c|c|c|c|}
\hline Taxon & Basin & Site $^{1}$ & $N$ & Sample code & $\operatorname{Depth}(\mathrm{m})^{2}$ & $\begin{array}{l}\text { Latitude } \\
(\mathrm{N})^{2}\end{array}$ & $\begin{array}{l}\text { Longitude } \\
(\mathrm{W})^{2}\end{array}$ & Year & Ship/Sampling method ${ }^{3}$ \\
\hline $\begin{array}{l}\text { Munida cf. } \\
\text { microphthalma }\end{array}$ & GOM & MC118 & 2 & LII10_2135-36 & 900 & $28^{\circ} 85.587^{\prime}$ & $88^{\circ} 49.356^{\prime}$ & 2010 & Ronald H. Brown/J2 \\
\hline Munida sanctipauli & GOM & VK826 & 1 & CH07_245_01 & 476 & $29^{\circ} 10.179^{\prime}$ & $88^{\circ} 00.790^{\prime}$ & 2007 & Cape Hatteras/BC \\
\hline Munida cf. sanctipauli & GOM & VK826 & 1 & SJ09_124 & 445 & $28^{\circ} 11.596^{\prime}$ & $89^{\circ} 48.108^{\prime}$ & 2009 & Seward Johnson/JSL \\
\hline Munida cf. sanctipauli & GOM & VK826 & 1 & SJ09_257 & 471 & $29^{\circ} 09.962^{\prime}$ & $88^{\circ} 00.708^{\prime}$ & 2009 & Seward Johnson/JSL \\
\hline Munida cf. sanctipauli & GOM & VK826 & 2 & CH10_044, 062 & $478-517$ & $\begin{array}{l}29^{\circ} 10.099^{\prime}- \\
29^{\circ} 10.071^{\prime}\end{array}$ & $\begin{array}{l}88^{\circ} 01.722^{\prime}- \\
88^{\circ} 00.550\end{array}$ & 2010 & Cape Hatteras/OT \\
\hline Munida cf. sanctipauli & GOM & VK826 & 2 & CH10_018,021 & $489-500$ & $\begin{array}{l}29^{\circ} 10.103^{\prime}- \\
29^{\circ} 09.883^{\prime}\end{array}$ & $\begin{array}{l}88^{\circ} 01.232^{\prime}- \\
88^{\circ} 00.159^{\prime}\end{array}$ & 2010 & Cape Hatteras/OT \\
\hline Munida cf. sanctipauli & GOM & VK826 & 2 & CH10_036-037 & $488-526$ & $\begin{array}{l}29^{\circ} 10.191^{\prime}- \\
29^{\circ} 10.179^{\prime}\end{array}$ & $\begin{array}{l}88^{\circ} 00.873^{\prime}- \\
88^{\circ} 00.757^{\prime}\end{array}$ & 2010 & Cape Hatteras/K2 \\
\hline Munida cf. sanctipauli & NWA & $\mathrm{CF}$ & 1 & 4897_01 & 390 & $33^{\circ} 34.220^{\prime}$ & $76^{\circ} 27.744^{\prime}$ & 2005 & Seward Johnson/JSL \\
\hline Munida valida & NWA & $\mathrm{CCN}$ & 1 & SJ09_374 & $408-446$ & $\begin{array}{l}28^{\circ} 23.152^{\prime}- \\
28^{\circ} 23.342^{\prime}\end{array}$ & $\begin{array}{l}79^{\circ} 45.989^{\prime}- \\
79^{\circ} 45.986^{\prime}\end{array}$ & 2009 & Seward Johnson/JSL \\
\hline Munida valida & NWA & CLO & 1 & CH06_018_01 & $458-465$ & $\begin{array}{l}34^{\circ} 11.373^{\prime}- \\
34^{\circ} 10.426^{\prime}\end{array}$ & $\begin{array}{l}75^{\circ} 52.742^{\prime} \\
75^{\circ} 53.155^{\prime}\end{array}$ & 2006 & Cape Hatteras/OT \\
\hline Munida valida & NWA & CLO & 1 & SJ04_35_01 & $657-910$ & $\begin{array}{l}34^{\circ} 12.556^{\prime}- \\
34^{\circ} 12.937^{\prime}\end{array}$ & $\begin{array}{l}75^{\circ} 46.292^{\prime}- \\
75^{\circ} 44.540^{\prime}\end{array}$ & 2004 & Seward Johnson/OT \\
\hline Munida valida & NWA & $\mathrm{NC}$ & 1 & MAC217 & 458 & $37^{\circ} 05.714^{\prime}$ & $74^{\circ} 57.889^{\prime}$ & 2013 & Ronald H. Brown/J2 \\
\hline Munida cf. valida & GOM & VK826 & 2 & CH10_022-023 & $478-500$ & $\begin{array}{l}29^{\circ} 09.962^{\prime}- \\
29^{\circ} 09.749^{\prime}\end{array}$ & $\begin{array}{l}88^{\circ} 01.049^{\prime}- \\
88^{\circ} 01.193^{\prime}\end{array}$ & 2010 & Cape Hatteras/OT \\
\hline
\end{tabular}




\begin{tabular}{|c|c|c|c|c|c|c|c|c|c|}
\hline Taxon & Basin & Site $^{1}$ & $N$ & Sample code & $\operatorname{Depth}(\mathbf{m})^{2}$ & $\begin{array}{l}\text { Latitude } \\
(\mathrm{N})^{2}\end{array}$ & $\begin{array}{l}\text { Longitude } \\
(\mathrm{W})^{2}\end{array}$ & Year & Ship/Sampling method \\
\hline Munida cf. valida & GOM & VK826 & 5 & $\begin{array}{l}\text { CH10_045-048, } \\
064\end{array}$ & $478-517$ & $\begin{array}{l}29^{\circ} 10.099^{\prime}- \\
29^{\circ} 10.071^{\prime}\end{array}$ & $\begin{array}{l}88^{\circ} 01.722^{\prime}- \\
88^{\circ} 00.550^{\prime}\end{array}$ & 2010 & Cape Hatteras/OT \\
\hline Munidopsis bermudezi & GOM & AC818 & 1 & J2282_01 & 2746 & $26^{\circ} 10.785^{\prime}$ & $94^{\circ} 97.289^{\prime}$ & 2007 & Ronald H. Brown/J2 \\
\hline Munidopsis curvirostra & GOM & WR269 & 1 & WR269_01 & 1919 & $26^{\circ} 41.187^{\prime}$ & $91^{\circ} 39.780^{\prime}$ & 2007 & Ronald H. Brown/J2 \\
\hline Munidopsis curvirostra & NWA & $\mathrm{NC}$ & 1 & MAC277 & 1682 & $36^{\circ} 53.960^{\prime}$ & $74^{\circ} 27.520^{\prime}$ & 2013 & Ronald H. Brown/OT \\
\hline Munidopsis curvirostra & NWA & $\mathrm{NC}$ & 2 & MAC280-81 & 1603 & $37^{\circ} 04.322^{\prime}$ & $74^{\circ} 25.064^{\prime}$ & 2013 & Ronald H. Brown/OT \\
\hline Munidopsis livida & GOM & AC818 & 1 & $\mathrm{~J} 2282-02$ & 2746 & $26^{\circ} 10.785^{\prime}$ & $94^{\circ} 97.289^{\prime}$ & 2007 & Ronald H. Brown/J2 \\
\hline Munidopsis penescabra & GOM & VK826 & 2 & $\begin{array}{l}\text { CH07_226_01- } \\
02\end{array}$ & $350-477$ & $\begin{array}{l}29^{\circ} 09.703^{\prime}- \\
29^{\circ} 10.621^{\prime}\end{array}$ & $\begin{array}{l}88^{\circ} 01.112^{\prime}- \\
88^{\circ} 00.548^{\prime}\end{array}$ & 2007 & Cape Hatteras/TT \\
\hline Munidopsis similis & GOM & AT340 & 1 & 4179_01 & 2184 & $27^{\circ} 38.698^{\prime}$ & $88^{\circ} 21.873^{\prime}$ & 2006 & Atlantis/Alvin \\
\hline Munidopsis similis & GOM & AT340 & 1 & J2270_01 & 2192 & $27^{\circ} 38.694^{\prime}$ & $88^{\circ} 21.843^{\prime}$ & 2007 & Ronald H. Brown/J2 \\
\hline Munidopsis similis & GOM & GC852 & 1 & CH07_42_02 & $1478-1574$ & $\begin{array}{l}27^{\circ} 09.628^{\prime}- \\
27^{\circ} 10.643\end{array}$ & $\begin{array}{l}91^{\circ} 09.915^{\prime}- \\
91^{\circ} 09.879^{\prime}\end{array}$ & 2007 & Cape Hatteras/OT \\
\hline Munidopsis sp. A & GOM & AC818 & 1 & 4195_01 & 2744 & $26^{\circ} 10.181^{\prime}$ & $94^{\circ} 37.368^{\prime}$ & 2006 & Atlantis/Alvin \\
\hline Munidopsis sp. A & GOM & AC818 & 1 & $\mathrm{~J} 2282 \_03$ & 2746 & $26^{\circ} 10.785^{\prime}$ & $94^{\circ} 97.289$ & 2007 & Ronald H. Brown/J2 \\
\hline Munidopsis sp. B & GOM & GC600 & 1 & Msis4174_01 & 1250 & $27^{\circ} 22.123^{\prime}$ & $90^{\circ} 33.982^{\prime}$ & 2006 & Atlantis/Alvin \\
\hline Munidopsis sp. B & GOM & GB543 & 1 & 4586_01 & 521 & $27^{\circ} 26.483^{\prime}$ & $93^{\circ} 10.917^{\prime}$ & 2003 & Seward Johnson/JSL \\
\hline Munidopsis sp. C & GOM & WFS & 1 & CH10_216 & $401-435$ & $\begin{array}{l}29^{\circ} 04.350^{\prime}- \\
29^{\circ} 04.496^{\prime}\end{array}$ & $\begin{array}{l}88^{\circ} 22.975^{\prime}- \\
88^{\circ} 22.699^{\prime}\end{array}$ & 2010 & Cape Hatteras/K2 \\
\hline
\end{tabular}




\begin{tabular}{|c|c|c|c|c|c|c|c|c|c|}
\hline Taxon & Basin & Site $^{1}$ & $N$ & Sample code & $\operatorname{Depth}(\mathbf{m})^{2}$ & $\begin{array}{l}\text { Latitude } \\
(\mathrm{N})^{2}\end{array}$ & $\begin{array}{l}\text { Longitude } \\
(\mathrm{W})^{2}\end{array}$ & Year & Ship/Sampling method ${ }^{3}$ \\
\hline Munidopsis sp. C & GOM & WFS & 1 & CH10_145 & $478-500$ & $\begin{array}{l}29^{\circ} 09.962^{\prime}- \\
29^{\circ} 09.749^{\prime}\end{array}$ & $\begin{array}{l}88^{\circ} 01.049^{\prime}- \\
88^{\circ} 01.193^{\prime}\end{array}$ & 2010 & Cape Hatteras/K2 \\
\hline Munidopsis sp. C & GOM & AT047 & 1 & RB09_017 & 835 & $27^{\circ} 87.920^{\prime}$ & $88^{\circ} 21.222^{\prime}$ & 2009 & Ronald H. Brown/K2 \\
\hline Munidopsis sp. C & GOM & MC751 & 1 & RB09_073 & 450 & $28^{\circ} 18.967^{\prime}$ & $88^{\circ} 20.217^{\prime}$ & 2009 & Ronald H. Brown/J2 \\
\hline Munidopsis sp. C & GOM & VK826 & 1 & 4872_01 & 453 & $29^{\circ} 89.642^{\prime}$ & $88^{\circ} 01.163^{\prime}$ & 2005 & Seward Johnson/JSL \\
\hline Munidopsis sp. C & GOM & VK826 & 1 & CH07_226_03 & $350-477$ & $\begin{array}{l}29^{\circ} 09.7033^{\prime}- \\
29^{\circ} 10.621^{\prime}\end{array}$ & $\begin{array}{l}88^{\circ} 01.112^{\prime}- \\
88^{\circ} 00.548^{\prime}\end{array}$ & 2007 & Cape Hatteras/TT \\
\hline Munidopsis sp. C & GOM & VK826 & 3 & CH10_014-016 & $408-430$ & $\begin{array}{l}29^{\circ} 04.330^{\prime}- \\
29^{\circ} 04.338^{\prime}\end{array}$ & $\begin{array}{l}88^{\circ} 22.588^{\prime}- \\
88^{\circ} 22.465^{\prime}\end{array}$ & 2010 & Cape Hatteras/OT \\
\hline Munidopsis sp. C & GOM & VK862 & 1 & CH10_130 & $489-500$ & $\begin{array}{l}29^{\circ} 10.103^{\prime}- \\
29^{\circ} 09.883^{\prime}\end{array}$ & $\begin{array}{l}88^{\circ} 01.232^{\prime}- \\
88^{\circ} 00.159^{\prime}\end{array}$ & 2010 & Cape Hatteras/K2 \\
\hline Munidopsis sp. C & GOM & VK826 & 4 & CH10_032-035 & $488-526$ & $\begin{array}{l}29^{\circ} 10.191^{\prime}- \\
29^{\circ} 10.179^{\prime}\end{array}$ & $\begin{array}{l}88^{\circ} 00.873^{\prime}- \\
88^{\circ} 00.757^{\prime}\end{array}$ & 2010 & Cape Hatteras/K2 \\
\hline Munidopsis sp. C & GOM & VK826 & 1 & CH10_080 & $475-499$ & $\begin{array}{l}29^{\circ} 10.259^{\prime}- \\
29^{\circ} 10.324^{\prime}\end{array}$ & $\begin{array}{l}88^{\circ} 00.817^{\prime}- \\
88^{\circ} 00.718^{\prime}\end{array}$ & 2010 & Cape Hatteras/K2 \\
\hline Munidopsis sp. C & NWA & JAX & 2 & 4684_01-02 & $569-554$ & $\begin{array}{l}30^{\circ} 31.939^{\prime}- \\
30^{\circ} 30.842^{\prime}\end{array}$ & $\begin{array}{l}79^{\circ} 39.621^{\prime}- \\
79^{\circ} 39.624^{\prime}\end{array}$ & 2004 & Seward Johnson/JSL \\
\hline Munidopsis sp. D & NWA & $\mathrm{NC}$ & 2 & MAC428-29 & 1388 & $37^{\circ} 02.948^{\prime}$ & $74^{\circ} 30.604^{\prime}$ & 2013 & Ronald H. Brown/J2 \\
\hline Munidopsis sp. D & NWA & $\mathrm{HC}$ & 1 & ROPOS09 & 1049 & $41^{\circ} 03.490$ & $66^{\circ} 21.728^{\prime}$ & 2014 & Henry Bigelow/ROPOS \\
\hline Munidopsis sp. D & NWA & $\mathrm{CC}$ & 1 & ROPOS10 & 840 & $41^{\circ} 20.276^{\prime}$ & $66^{\circ} 08.801^{\prime}$ & 2014 & Henry Bigelow/ROPOS \\
\hline
\end{tabular}


${ }^{1}$ Gulf of Mexico (GOM) sites include lease block and number, and are listed West to East: $\mathrm{AC}=$ Alaminos Canyon, WR= Walker Ridge, GC= Green Canyon, AT= Atwater Valley, MC= Mississippi Canyon, VK= Viosca Knoll, WFS= West Florida Slope; Northwestern Atlantic sites (NWA) are listed North to South: $\mathrm{CC}=$ Corsair Canyon, $\mathrm{HC}=$ Heezen Canyon, $\mathrm{BC}=$ Baltimore Canyon, $\mathrm{NC}=$ Norfolk Canyon, $\mathrm{CLO}=\mathrm{Cape}$ Lookout, $\mathrm{CF}=\mathrm{Cape}$ Fear, JAX=Jacksonville, CCN=Cape Canaveral. ${ }^{2}$ Latitude/Longitude (in degrees decimal minutes) and depths are reported for sample event or when specific collection sites were uncertain, ranges from entire dive or trawl are presented. *Data from Roberts et al (2007); ${ }^{3} \mathrm{OT}=\mathrm{otter}$ trawl, TT=tucker trawl, BC=Box core, K2= remotely operated vehicle (ROV) Kraken2 (Northeast Underwater Research, Technology and Education Center, University of Connecticut), J2=ROV Jason2 (Woods Hole Oceanographic Institute), JSL=human operated vehicle (HOV) Johnson Sea-Link (Harbor Branch Oceanographic Institution), Alvin=HOV Alvin (Woods Hole Oceanographic Institute), ROPOS=ROV ROPOS (Canadian Scientific Submersible Facility) . Research vessels employed were: NOAA ships Nancy Foster, Ronald H. Brown, Henry Bigelow (National Oceanic and Atmospheric Administration), R/V Cape Hatteras (Duke University - University of North Carolina Oceanographic Consortium), R/V Atlantis (Woods Hole Oceanographic Institute), R/V Seward Johnson (Harbor Branch Oceanographic Institution). 
TABLE 2: Interspecific pairwise genetic distances (uncorrected $p$-distances, below the diagonal) and standard errors (above the diagonal) between Munida species.

\begin{tabular}{|c|c|c|c|c|c|c|c|c|c|c|c|c|c|c|}
\hline 1 & M. iris & NWA & 40 & & 0.016 & 0.016 & 0.016 & 0.016 & 0.016 & 0.016 & 0.006 & 0.017 & 0.014 & 0.016 \\
\hline 2 & M. microphthalma & GOM & 16 & 0.157 & & 0.014 & 0.015 & 0.017 & 0.015 & 0.017 & 0.016 & 0.015 & 0.015 & 0.016 \\
\hline 3 & M. sanctipauli & NWA & 10 & 0.158 & 0.122 & & 0.011 & 0.016 & 0.010 & 0.017 & 0.016 & 0.016 & 0.016 & 0.016 \\
\hline 4 & M. valida & NWA & 11 & 0.169 & 0.139 & 0.071 & & 0.016 & 0.012 & 0.016 & 0.016 & 0.015 & 0.016 & 0.015 \\
\hline 5 & M. intermedia & NEA & 24 & 0.170 & 0.165 & 0.185 & 0.192 & & 0.017 & 0.012 & 0.017 & 0.016 & 0.017 & 0.016 \\
\hline 6 & M. intermedia* & NEA & 1 & 0.165 & 0.126 & 0.060 & 0.087 & 0.182 & & 0.017 & 0.016 & 0.016 & 0.016 & 0.015 \\
\hline 7 & M. rugosa & NEA & 3 & 0.156 & 0.157 & 0.185 & 0.171 & 0.102 & 0.182 & & 0.016 & 0.016 & 0.016 & 0.017 \\
\hline 8 & M. rutllanti & NEA & 7 & 0.028 & 0.152 & 0.159 & 0.174 & 0.180 & 0.160 & 0.167 & & 0.017 & 0.014 & 0.016 \\
\hline 9 & M. gracilis & SWP & 54 & 0.170 & 0.144 & 0.162 & 0.163 & 0.181 & 0.167 & 0.163 & 0.163 & & 0.016 & 0.015 \\
\hline 10 & M. gregaria & SEP & 110 & 0.113 & 0.145 & 0.161 & 0.176 & 0.175 & 0.163 & 0.155 & 0.117 & 0.166 & & 0.016 \\
\hline 11 & M. thoe & WP & 34 & 0.179 & 0.153 & 0.151 & 0.152 & 0.183 & 0.152 & 0.178 & 0.180 & 0.153 & 0.184 & \\
\hline
\end{tabular}

${ }^{1} \mathrm{BGP}=$ Biogeographic province as defined in Schnabel et al (2011): NEA=North East Atlantic, SWP=South West Pacific, SEP=South East Pacific, WP=West Pacific, with the addition of NWA= North West Atlantic and GOM= Gulf of Mexico. *Genbank accession number JQ348884, divergent from other M. intermedia. 
TABLE 3: DNA sequence diversity summary statistics for species of Munida calculated in DnaSP.

\begin{tabular}{|c|c|c|c|c|c|c|c|c|c|c|c|c|c|c|c|c|c|}
\hline & BGP & $N$ & $n t$ & $p$ & $\mu$ & $s$ & $P I$ & syn & nsyn & $H$ & $H_{d}$ & $\sigma^{2} H_{d}$ & $\pi$ & $k$ & $p$-dist & $S E_{p}$ & $\mathrm{G}+\mathrm{C}$ \\
\hline M. iris & NWA & 40 & 499 & 27 & 29 & 9 & 18 & 28 & 1 & 25 & 0.954 & 0.000 & 0.013 & 6.40 & 0.013 & 0.003 & 0.348 \\
\hline M. microphthalma & GOM & 16 & 486 & 14 & 15 & 8 & 6 & 15 & 0 & 10 & 0.825 & 0.010 & 0.006 & 2.87 & 0.006 & 0.002 & 0.353 \\
\hline M. sanctipauli & NWA & 10 & 485 & 13 & 13 & 11 & 2 & 13 & 0 & 9 & 0.978 & 0.003 & 0.007 & 3.20 & 0.006 & 0.002 & 0.370 \\
\hline M. valida & NWA & 11 & 454 & 6 & 6 & 5 & 1 & 5 & 0 & 6 & 0.727 & 0.021 & 0.003 & 1.24 & 0.003 & 0.001 & 0.389 \\
\hline M. intermedia & NEA & 24 & 499 & 19 & 19 & 10 & 9 & 19 & 0 & 22 & 0.993 & 0.000 & 0.006 & 3.13 & 0.006 & 0.002 & 0.348 \\
\hline M. rutllanti & NEA & 7 & 482 & 7 & 8 & 5 & 2 & 5 & 3 & 5 & 0.857 & 0.019 & 0.005 & 2.62 & 0.005 & 0.002 & 0.357 \\
\hline M. gracilis & SWP & 54 & 499 & 46 & 50 & 32 & 14 & 47 & 0 & 36 & 0.953 & 0.000 & 0.007 & 3.50 & 0.007 & 0.002 & 0.373 \\
\hline M. gregaria & SEP & 110 & 479 & 30 & 31 & 19 & 11 & 29 & 2 & 33 & 0.628 & 0.003 & 0.002 & 0.99 & 0.002 & 0.000 & 0.328 \\
\hline M. thoe & WP & 34 & 492 & 31 & 37 & 18 & 13 & 37 & 0 & 33 & 0.998 & 0.000 & 0.009 & 4.24 & 0.009 & 0.002 & 0.382 \\
\hline
\end{tabular}

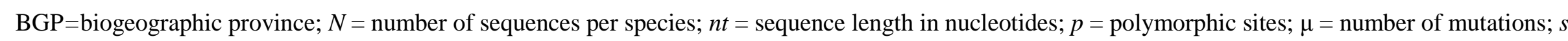

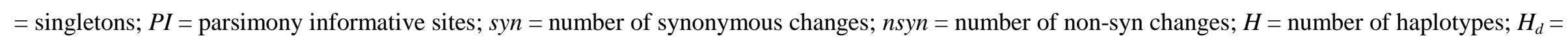

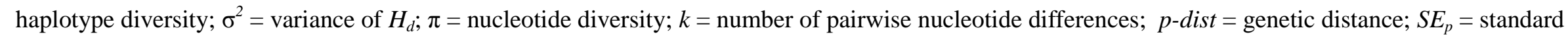
error of $p$-dist, based on 500 bootstrap replicates; $\mathrm{G}+\mathrm{C}=$ proportion of guanine and cytosine nucleotide bases 
TABLE 4: Interspecific pairwise genetic distances (uncorrected $p$-distances, below the diagonal) and standard errors ( above the diagonal) between species of Munidopsis.

\begin{tabular}{|c|c|c|c|c|c|c|c|c|c|c|c|c|c|c|c|c|c|c|c|c|c|}
\hline & Taxon & BGP & $N$ & 1 & 2 & 3 & 4 & 5 & 6 & 7 & 8 & 9 & 10 & 11 & 12 & 13 & 14 & 15 & 16 & 17 & 18 \\
\hline 1 & M. abbreviata & GOM & 1 & & 0.018 & 0.019 & 0.018 & 0.017 & 0.019 & 0.018 & 0.018 & 0.019 & 0.019 & 0.018 & 0.016 & 0.018 & 0.017 & 0.018 & 0.020 & 0.017 & 0.017 \\
\hline 2 & M. aries & NEA & 1 & 0.193 & & 0.015 & 0.019 & 0.020 & 0.014 & 0.017 & 0.016 & 0.020 & 0.020 & 0.020 & 0.019 & 0.015 & 0.016 & 0.014 & 0.021 & 0.018 & 0.018 \\
\hline 3 & M. bermudezi & GOM & 1 & 0.197 & 0.107 & & 0.019 & 0.019 & 0.014 & 0.015 & 0.015 & 0.020 & 0.021 & 0.020 & 0.019 & 0.014 & 0.015 & 0.014 & 0.021 & 0.019 & 0.018 \\
\hline 4 & M. curvirostra & WA & 7 & 0.160 & 0.220 & 0.207 & & 0.018 & 0.018 & 0.019 & 0.017 & 0.018 & 0.018 & 0.018 & 0.015 & 0.017 & 0.017 & 0.018 & 0.019 & 0.017 & 0.018 \\
\hline 5 & M. erinacea & GOM & 1 & 0.164 & 0.217 & 0.201 & 0.188 & & 0.019 & 0.019 & 0.019 & 0.019 & 0.019 & 0.019 & 0.016 & 0.018 & 0.019 & 0.019 & 0.020 & 0.016 & 0.017 \\
\hline 6 & M. exuta & MAR* & 2 & 0.193 & 0.112 & 0.103 & 0.215 & 0.215 & & 0.016 & 0.015 & 0.019 & 0.020 & 0.019 & 0.019 & 0.008 & 0.014 & 0.007 & 0.021 & 0.018 & 0.018 \\
\hline 7 & M. lauensis & WP & 116 & 0.202 & 0.156 & 0.121 & 0.217 & 0.215 & 0.145 & & 0.015 & 0.019 & 0.020 & 0.019 & 0.019 & 0.014 & 0.015 & 0.015 & 0.021 & 0.019 & 0.018 \\
\hline 8 & M. livida & GOM & 1 & 0.183 & 0.154 & 0.126 & 0.204 & 0.196 & 0.123 & 0.154 & & 0.018 & 0.019 & 0.019 & 0.018 & 0.014 & 0.015 & 0.014 & 0.020 & 0.018 & 0.018 \\
\hline 9 & M. longimanus & GOM & 1 & 0.186 & 0.225 & 0.212 & 0.185 & 0.182 & 0.247 & 0.245 & 0.198 & & 0.020 & 0.021 & 0.017 & 0.019 & 0.019 & 0.019 & 0.008 & 0.019 & 0.020 \\
\hline 10 & M. opalescens & SEP & 1 & 0.159 & 0.207 & 0.210 & 0.155 & 0.159 & 0.196 & 0.202 & 0.185 & 0.196 & & 0.018 & 0.017 & 0.019 & 0.019 & 0.019 & 0.021 & 0.019 & 0.019 \\
\hline 11 & M. penescabra & GOM & 2 & 0.143 & 0.238 & 0.215 & 0.181 & 0.192 & 0.216 & 0.223 & 0.213 & 0.230 & 0.136 & & 0.017 & 0.019 & 0.019 & 0.019 & 0.021 & 0.018 & 0.019 \\
\hline 12 & M. polymorpha & NEA & 2 & 0.144 & 0.229 & 0.212 & 0.136 & 0.142 & 0.218 & 0.231 & 0.196 & 0.167 & 0.134 & 0.146 & & 0.018 & 0.018 & 0.018 & 0.018 & 0.016 & 0.017 \\
\hline 13 & M. recta & $\mathrm{EPR}^{*}$ & 18 & 0.172 & 0.131 & 0.104 & 0.199 & 0.193 & 0.040 & 0.118 & 0.099 & 0.224 & 0.170 & 0.197 & 0.210 & & 0.013 & 0.007 & 0.020 & 0.017 & 0.017 \\
\hline 14 & M. similis & GOM & 3 & 0.174 & 0.146 & 0.122 & 0.183 & 0.208 & 0.117 & 0.142 & 0.130 & 0.219 & 0.179 & 0.198 & 0.189 & 0.093 & & 0.013 & 0.020 & 0.018 & 0.018 \\
\hline 15 & M. $s p A$ & GOM & 2 & 0.177 & 0.112 & 0.108 & 0.204 & 0.199 & 0.031 & 0.127 & 0.113 & 0.227 & 0.178 & 0.212 & 0.208 & 0.028 & 0.097 & & 0.020 & 0.017 & 0.017 \\
\hline 16 & M. $s p B$ & GOM & 2 & 0.194 & 0.248 & 0.231 & 0.188 & 0.195 & 0.248 & 0.250 & 0.213 & 0.027 & 0.194 & 0.232 & 0.180 & 0.231 & 0.227 & 0.233 & & 0.020 & 0.020 \\
\hline 17 & M. $s p C$ & WA & 17 & 0.165 & 0.212 & 0.207 & 0.175 & 0.147 & 0.201 & 0.213 & 0.212 & 0.209 & 0.185 & 0.186 & 0.168 & 0.186 & 0.202 & 0.190 & 0.211 & & 0.015 \\
\hline 18 & M. $s p D$ & NWA & 4 & 0.177 & 0.222 & 0.193 & 0.202 & 0.163 & 0.218 & 0.211 & 0.205 & 0.218 & 0.177 & 0.211 & 0.185 & 0.202 & 0.213 & 0.208 & 0.238 & 0.137 & \\
\hline
\end{tabular}


Taxa in bold include those collected in this study. BGP (biogeographic province) reflects where specimens were collected, not necessarily the entire species distribution. WA= collected in both NWA + GOM. *Regions not defined in Schnabel et al (2011); MAR= Mid-Atlantic Ridge, EPR= East Pacific Rise.

TABLE 5: DNA sequence summary statistics for species of Munidopsis calculated in DnaSP.

\begin{tabular}{lcccccccccccccccccccccc}
\hline & BGP & $N$ & $n t$ & $p$ & $\mu$ & $s$ & $P I S$ & $s y n$ & $n s y n$ & $H$ & $H_{d}$ & $\sigma^{2} H_{d}$ & $\pi$ & $k$ & $p$-dist & $S E_{p}$ & $\mathrm{G}+\mathrm{C}$ \\
\hline Munidopsis sp C & WA & 17 & 434 & 9 & 9 & 5 & 4 & 9 & 0 & 9 & 0.86 & 0.005 & 0.004 & 1.65 & 0.004 & 0.001 & 0.395 \\
Munidopsis sp D & WA & 4 & 454 & 0 & 0 & 0 & 0 & 0 & 0 & 1 & 0.00 & 0.000 & 0.000 & 0.00 & 0.000 & 0.000 & 0.441 \\
Munidopsis curvirostra & WA & 7 & 454 & 4 & 4 & 4 & 0 & 3 & 1 & 2 & 0.29 & 0.039 & 0.003 & 1.14 & 0.003 & 0.001 & 0.346 \\
Munidopsis lauensis & WP & 116 & 454 & 4 & 4 & 4 & 0 & 3 & 1 & 5 & 0.07 & 0.001 & 0.000 & 0.07 & 0.000 & 0.000 & 0.438 \\
Munidopsis recta & EPR & 18 & 453 & 7 & 7 & 5 & 2 & 5 & 2 & 7 & 0.74 & 0.010 & 0.003 & 1.19 & 0.003 & 0.001 & 0.382 \\
\hline
\end{tabular}

BGP = biogeographic province; $N=$ number of sequences per species; $n t=$ sequence length in nucleotides; $p=$ polymorphic sites; $\mu=$ number of mutations; $s=$ singletons; $P I=$ parsimony informative sites; syn = number of synonymous changes; $n s y n=$ number of non-syn changes; $H=$ number of haplotypes; $H_{d}=$ haplotype diversity; $\sigma^{2}=$ variance of $H_{d} ; \pi=$ nucleotide diversity; $k=$ number of pairwise nucleotide differences; $p$-dist = genetic distance; $S E_{p}=$ standard error of $p$-dist, based on 500 bootstrap replicates; $\mathrm{G}+\mathrm{C}=$ proportion of guanine and cytosine nucleotide bases

See Table 2 and 3 for abbreviations and variables. 